\title{
Krzysztof Persak
}

persak@isppan.waw.pl

\section{Co dziś wiemy o niemieckich represjach za pomoc udzielaną Żydom?}

\author{
Represje za pomoc Żydom na okupowanych ziemiach polskich $w$ czasie \\ II wojny światowej, t. 1, red. Martyna Grądzka-Rejak, Aleksandra \\ Namysło, Warszawa: IPN, 2019, 464 s.
}

\section{Streszczenie}

Autor artykułu omawia i poddaje kwantyfikacji wyniki najnowszych badań nad niemieckimi represjami za pomaganie Żydom na okupowanych ziemiach polskich podczas drugiej wojny światowej. Druga warstwa artykułu obejmuje analizę uwarunkowań politycznych, w jakich są dziś prowadzone w Polsce takie badania, i ich uwikłania w oficjalną państwową politykę pamięci. Analiza konstrukcji i języka publikacji, w której przedstawiono wyniki tych badań, ujawnia obszary istniejących tabu i pokazuje defensywny charakter współczesnego dyskursu o ratowaniu Żydów.

\section{Słowa kluczowe}

zagłada Żydów, Holokaust, Sprawiedliwi, ludobójstwo, represje niemieckie, druga wojna światowa, okupacja niemiecka, ratowanie Żydów

\begin{abstract}
The author discusses and quantifies the results of recent research of the German repressions for help offered to Jews in occupied Poland during World War II. Another layer of the paper covers an analysis of the political underpinnings of research on this subject conducted in today's Poland, and its entanglement in the official politics of memory. Analysis of the construction and of the language of the publication which presents the research results, reveals areas of existing taboos and shows the defensive character of the contemporary discourse of rescuing Jews.
\end{abstract}

\section{Key words}

Holocaust, the Righteous, genocide, German repressions, World War II, German occupation of Poland, rescuing Jews 
Kwestia pomocy dla Żydów, a zwłaszcza represji stosowanych przez niemieckiego okupanta za jej udzielanie, jest stałym argumentem przetargowym w polsko-żydowskich i polsko-polskich sporach o postawy Polaków wobec Żydów podczas Holokaustu ${ }^{1}$. Początków dyskursu defensywnego można się doszukać już w publikacjach konspiracyjnych powstałych w okresie wojny ${ }^{2}$. Poczynając od debaty prasowej po pogromie kieleckim w 1946 r., polska pomoc Żydom przywoływana jest jako kontrargument, ilekroć w przestrzeni publicznej pojawi się problem antysemityzmu, obojętności Polaków wobec zagłady Żydów czy wręcz ich przyczyniania się do Zagłady ${ }^{3}$. Sprawiedliwi są regularnie wzywani na pomoc, by dać odpór oskarżeniom Polaków o winy wobec Żydów ${ }^{4}$.

Tempo tej licytacji wyraźnie wzrosło w ostatnim dwudziestoleciu, po publikacji w 2000 roku Sąsiadów Jana Tomasza Grossa ${ }^{5}$. Opisując w książce o zbrodni w Jedwabnem przypadek masowego mordu Żydów dokonanego bezpośrednio przez Polaków, Gross przekroczył dotychczas dopuszczalne granice opowieści o stosunkach polsko-żydowskich podczas wojny, w której ekstremum zachowań negatywnych oprócz obojętności i niechęci wobec Żydów stanowiły szmalcownictwo i przypadki denuncjacji. To był jednak dopiero początek. Złamanie tabu zaowocowało gwałtownym rozwojem nurtu historiografii poświęconego postawom Polaków wobec Żydów w całej ich złożoności. Liczne prace, w tym uzyskujące duży rozgłos kolejne książki Jana Tomasza Grossa ${ }^{6}$, podjęły m.in. problem wydawania szukających ratunku Żydów Niemcom, a także nierzadkich przypadków ich mordowania oraz kwestię zabójstw i pogromów Żydów w pierwszych latach po wojnie ${ }^{7}$. Poczesne miejsce $\mathrm{w}$ tym nurcie historiografii zajmują prace

${ }^{1}$ Dariusz Libionka, Polskie piśmiennictwo na temat zorganizowanej i indywidualnej pomocy Żydom (1945-2008), „Zagłada Żydów. Studia Materiały” 2008, nr 4.

${ }^{2}$ Por. Lata czterdzieste. Początki polskiej narracji o Zagładzie, red. Maryla Hopfinger, Tomasz Żukowski, Warszawa: IBL PAN, 2019; Opowieść o niewinności. Kategoria świadka Zagłady w kulturze polskiej (1942-2015), red. Maryla Hopfinger, Tomasz Żukowski, Warszawa: IBL PAN, 2019.

${ }^{3}$ Dariusz Libionka, Antysemityzm i Zagłada na łamach prasy w Polsce w latach 1945-1946, „Polska 1944/45. Studia i materiały” 1997, nr 2.

${ }^{4}$ Tomasz Żukowski, Wielki retusz. Jak zapomnieliśmy, że Polacy zabijali Żydów, Warszawa: Wielka Litera, 2018, rozdział 3 „Sprawiedliwi na straży tabu”; Piotr Forecki, Od „Shoah” do „Strachu”. Spory o polsko-żydowska przeszłość i pamięć w debatach publicznych, Poznań: Wydawnictwo Poznańskie, 2010.

${ }^{5}$ Jan Tomasz Gross, Sąsiedzi. Historia zagłady żydowskiego miasteczka, Sejny: Pogranicze, 2000.

${ }^{6}$ Jan Tomasz Gross, Strach. Antysemityzm w Polsce tuż po wojnie. Historia moralnej zapaści, Kraków: Znak, 2008; Jan Tomasz Gross, Irena Grudzińska-Gross, Złote żniwa. Rzecz o tym, co się działo na obrzeżach zagłady Żydów, Kraków: Znak, 2011.

${ }^{7}$ Anna Cichopek, Pogrom Żydów w Krakowie 11 sierpnia 1945, Warszawa: ŻıH, 2000; Tomasz Szarota, U progu Zagłady. Zajścia antyżydowskie i pogromy w okupowanej Europie Warszawa, Paryż, Amsterdam, Antwerpia, Kowno, Warszawa: Sic!, 2000; Wokół Jedwabnego, t. 1-2, red. Paweł Machcewicz, Krzysztof Persak, Warszawa: IPN, 2002; Anna Bikont, My z Je- 
powstałe w kręgu Centrum Badań nad Zagładą Żydów IFiS PAN, w tym piętnaście tomów rocznika „Zagłada Żydów. Studia i Materiały” (2005-2019) ${ }^{8}$.

Reakcją na zachodzącą zmianę obrazu tego, co się podczas wojny i tuż po niej wydarzyło między Polakami i Żydami, był renesans zainteresowania problematyką pomocy niesionej Żydom. Wyrażał się on szybkim przyrostem publikacji

dwabnego, Warszawa: Prószyński i S-ka, 2004; Polacy i Żydzi pod okupacja niemiecka 19391945. Studia i materiały, red. Andrzej Żbikowski, Warszawa: IPN, 2006; Andrzej Żbikowski, U genezy Jedwabnego. Żydzi na Kresach Północno-Wschodnich II Rzeczypospolitej wrzesień 1939 - lipiec 1941, Warszawa: ŻIH, 2006; Wokół pogromu kieleckiego, red. Łukasz Kamiński, Jan Żaryn, Warszawa: IPN, 2006; Krzysztof Kaczmarski, Pogrom, którego nie było. Rzeszów 11-12 czerwca 1945 r. Fakty, hipotezy, dokumenty, Rzeszów: IPN, 2008; Martyna Rusiniak, Obóz zagłady Treblinka II w pamięci społecznej (1943-1989), Warszawa: Neriton, 2008; Witold Mędykowski, W cieniu gigantów. Pogromy 1941 r. w byłej sowieckiej strefie okupacyjnej kontekst historyczny, społeczny i kulturowy, Warszawa: ISP PAN, 2012; Joanna Tokarska-Bakir, Okrzyki pogromowe. Szkice z antropologii historycznej Polski lat 1939-1946, Wołowiec: Czarne, 2012; Następstwa zagłady Żydów. Polska 1944-2010, red. Feliks Tych, Monika Adamczyk-Garbowska, Lublin: UMCS i ŻIH, 2012; Inferno of Choices. Poles and the Holocaust, red. Sebastian Rejak, Elżebita Frister, Warsaw: Rytm, 2012; Alina Cała, Ochrona bezpieczeństwa fizycznego Żydów w Polsce powojennej. Komisje specjalne przy Centralnym Komitecie Żydów w Polsce, Warszawa: ŻıH, 2014; Mirosław Tryczyk, Miasta śmierci. Sqciedzkie pogromy Żydów, Warszawa: Wydawnictwo RM, 2015; Łukasz Krzyżanowski, Dom, którego nie było. Powroty ocalałych do powojennego miasta, Wołowiec: Czarne, 2016; Anna Bikont, Sendlerowa. W ukryciu, Wołowiec: Czarne, 2017; Joanna Tokarska-Bakir, Pod klątwq. Społeczny portret pogromu kieleckiego, t. 1-2, Warszawa: Czarna Owca, 2018; Pogromy Żydów na ziemiach polskich w XIX i XX wieku, t. 4: Holocaust i powojnie (1939-1946), red. August Grabski, Warszawa: IH PAN i in., 2019; Justyna Kowalska-Leder, „Nie wiem, jak mam ich cenić...” Strefa ambiwalencji w świadectwach Polaków i Żydów, Warszawa: IBL PAN, 2019; Jan Grabowski, Na posterunku. Udział polskiej policji granatowej i kryminalnej w zagładzie Żydów, Wołowiec: Czarne, 2020.

${ }^{8}$ Barbara Engelking, Szanowny panie gistapo. Donosy do władz niemieckich $w$ Warszawie i okolicach w latach 1940-1941, Warszawa: IFiS PAN, 2003; Jan Grabowski, „Ja tego żyda znam!". Szantażowanie Żydów w Warszawie, 1939-1943, Warszawa: IFiS PAN, 2004; Prowincja noc. Życie i zagłada Żydów $w$ dystrykcie warszawskim, red. Barbara Engelking, Jacek Leociak, Dariusz Libionka, Warszawa: IFiS PAN, 2007; Barbara Engelking, „Jest taki piękny słoneczny dzień". Losy Żydów szukających ratunku na wsi polskiej 1942-1945, Warszawa: Stowarzyszenie Centrum Badań nad Zagładą Żydów, 2011; Zarys krajobrazu. Wieś polska wobec zagłady Żydów 1942-1945, red. Barbara Engelking, Jan Grabowski, wstęp Krzysztof Persak, Warszawa: Stowarzyszenie Centrum Badań nad Zagładą Żydów, 2011; Jan Grabowski, Judenjagd. Polowanie na Żydów 1942-1945. Studium dziejów pewnego powiatu, Warszawa: Stowarzyszenie Centrum Badań nad Zagładą Żydów, 2011; Tadeusz Markiel, Alina Skibińska, „Jakie to ma znaczenie, czy zrobili to z chciwości?” Zagłada domu Trynczerów, Warszawa: Stowarzyszenie Centrum Badań nad Zagładą Żydów, 2011; Klucze i kasa. O mieniu żydowskim w Polsce pod okupacja niemiecka i we wczesnych latach powojennych 1939-1950, red. Jan Grabowski, Dariusz Libionka, Warszawa: Stowarzyszenie Centrum Badań nad Zagładą Żydów, 2014; Dalej jest noc. Losy Żydów w wybranych powiatach okupowanej Polski, t. 1-2, red. Barbara Engelking, Jan Grabowski, Warszawa: Stowarzyszenie Centrum Badań nad Zagładą Żydów, 2018. 
zarówno naukowych ${ }^{9}$, jak i popularyzatorskich, polemicznych oraz hagiograficznych ${ }^{10}$, a także rozmaitych przedsięwzięć w sferze pedagogiki społecznej i szeroko rozumianej polityki historycznej (wystawy, serwisy internetowe,

${ }^{9}$ Ten jest z ojczyzny mojej. Polacy z pomocą Żydom 1939-1945, oprac. Władysław Bartoszewski, Zofia Lewinówna, Warszawa: Świat Książki, 2007 (pierwsze wznowienie tej pionierskiej książki po 1969 r.); Jacek Młynarczyk, Sebastian Piątkowski, Cena poświęcenia. Zbrodnie na Polakach za pomoc udzielaną Żydom w rejonie Ciepielowa, Kraków: ISS, 2007; Elżbieta Rączy, Pomoc Polaków dla ludności żydowskiej na Rzeszowszczyźnie 1939-1945, Rzeszów: IPN, 2008; Księga Sprawiedliwych wśród Narodów Świata. Ratujący Żydów podczas Holocaustu. Polska, red. Israel Gutman, red. wyd. polskiego Dariusz Libionka, Robert Kuwałek, Adam Kopciowski, Kraków: Fundacja Instytut Studiów Strategicznych, 2009; „Kto w takich czasach Żydów przechowuje?...” Polacy niosący pomoc ludności żydowskiej w okresie okupacji niemieckiej, red. Aleksandra Namysło, Warszawa: IPN, 2009; Mateusz Szpytma, The Risk of Survival. The Rescue of the Jews by the Poles and the Tragic Consequences for the Ulma Family, Warszawa: IPN, 2009; Kazimierz Iranek-Osmecki, Kto ratuje jedno życie... Polacy i Żydzi 1939-1945, Warszawa: IPN, 2009 (wznowienie książki wydanej w Londynie w 1968 r.); Jacek Leociak, Ratowanie. Opowieści Polaków i Żydów, Kraków: Wydawnictwo Literackie, 2010; Karol Madaj, Małgorzata Żuławnik, Proboszcz getta, Warszawa: IPN, 2010; Ewa Kurek, Dzieci żydowskie w klasztorach. Udziat żeńskich zgromadzeń zakonnych $w$ akcji ratowania dzieci żydowskich w Polsce $w$ latach 19391945, Zakrzewo: Replika, 2012; Relacje o pomocy udzielanej Żydom przez Polaków w latach 1939-1945, t. 1: Dystrykt warszawski Generalnego Gubernatorstwa, red. Sebastian Piątkowski, Warszawa: IPN, 2018; Teresa Prekerowa, Konspiracyjna Rada Pomocy Żydom w Warszawie 1942-1945, Warszawa: PIW, 2019 (wznowienie pracy wydanej w 1982 r.); Relacje o pomocy udzielanej Żydom przez Polaków w latach 1939-1945, t. 2: Dystrykt krakowski Generalnego Gubernatorstwa, red. Sebastian Piątkowski, Warszawa: IPN, 2020; Roman Gieroń, Półmrok. Procesy karne w sprawie przestępstw okupacyjnych popełnionych przez chłopów wobec Żydów $w$ województwie krakowskim, Kraków: IPN 2020; Relacje o pomocy udzielanej Żydom przez Polaków w latach 1939-1945, t. 3: Dystrykt lubelski Generalnego Gubernatorstwa, red. Sebastian Piątkowski, Warszawa: IPN, 2020; Relacje o pomocy udzielanej Żydom przez Polaków w latach 1939-1945, t. 4: Dystrykt radomski Generalnego Gubernatorstwa, red. Sebastian Piątkowski, Warszawa: IPN, 2020 (plany obejmują siedem tomów serii).

${ }^{10}$ Godni synowie naszej Ojczyzny. Świadectwa nadesłane na apel Radia Maryja, t. 1-2, red. Alicja Augustyniak, Warszawa: Wydawnictwo Sióstr Loretanek, 2002; Polacy ratujący Żydów w latach II wojny światowej, oprac. Kamila Sachnowska, Katarzyna Cegieła, Karol Madaj, Olga Tumińska, Warszawa: IPN, 2008; Marek Jan Chodakiewicz, Po zagładzie. Stosunki polsko-żydowskie 1944-1947, Warszawa: IPN, 2008; „Jak ci się uda uratować, pamiętaj”. Relacje „Sprawiedliwych” i o "Sprawiedliwych” z województwa zachodniopomorskiego, red. Paweł Knap, Szczecin 2010; Stefan Korboński, Polacy, Żydzi i Holocaust, Warszawa: IPN, 2011 (tłumaczenie z oryginału angielskiego z 1986 r.); Elżbieta Rączy, Igor Witowicz, Polacy ratujący Żydów na Rzeszowszczyźnie w latach 1939-1945, Rzeszów: IPN, 2011; Złote serca czy złote żniwa? Studia nad wojennymi losami Polaków i Żydów, Warszawa: The Facto, 2011; Mord w Jedwabnem 10 lipca 1941. Prolog, przebieg, pokłosie, Kraków: Wyd. Arkadiusz Wingert, 2012; Edward Kopówka, Paweł Rytel-Andrianik, Dam im imię na wieki. Polacy z okolic Treblinki ratujący Żydów, Oxford-Treblinka: Wydawnictwo Sióstr Loretanek, 2011; Grzegorz Górny, Sprawiedliwi. Jak Polacy ratowali Żydów przed Zagłada, Izabelin-Warszawa: Rosikon Press, 2013; Jarosław Szarek, Mateusz Szpytma, Rodzina Ulmów. W hołdzie miłosiernym. Przejmująca historia polskiej rodziny, która poświęciła swoje życie, ratując Żydów, Kraków: Rafael, 2014; Jan Żaryn, 
filmy dokumentalne i fabularne, projekty dokumentacyjne i muzealne, pomniki, znaczki pocztowe, monety i inne upamiętnienia, enuncjacje oficjalne, uroczystości i święta państwowe). Część tych inicjatyw miała oddolny charakter społeczny, inne zaistniały przy silnym zaangażowaniu aparatu (i budżetu) państwa. Ważnymi graczami na tym polu są m.in. Instytut Pamięci Narodowej ${ }^{11}$ i Instytut Solidarności i Męstwa im. Witolda Pileckiego (używający na co dzień nazwy Instytut Pileckiego ${ }^{12}$. Choćby pobieżne omówienie wszystkich tych działań i komunikatów, jakie niosą, wykracza poza ramy niniejszego artykułu; uczynił to zresztą niedawno Piotr Forecki ${ }^{13}$. Ich wspólnym mianownikiem jest przekaz, że pomaganie Żydom było postawą powszechną.

Za symboliczny początek tego procesu można uznać powołanie w trakcie narodowej debaty o zbrodni w Jedwabnem społecznego Komitetu dla Upamiętnienia Polaków Ratujących Żydów ${ }^{14}$, na którego czele stanął ówczesny główny polemista Grossa prof. Tomasz Strzembosz. Niedawnymi najmocniejszymi akcentami były zaś otwarcie przez prezydenta RP w marcu 2016 r. w Markowej koło Łańcuta Muzeum Polaków Ratujących Żydów podczas II Wojny Światowej im. Rodziny Ulmó $w^{15}$ oraz ustanowienie w 2018 r. ustawą sejmową Narodowego Dnia Pamięci Polaków ratujących Żydów pod okupacją niemiecką, który wyznaczono na 24 marca - rocznicę niemieckiego mordu na rodzinie Ulmów ${ }^{16}$. Zapewne nie przez przypadek ustawę tę uchwalono w szczycie międzynarodowego

Polacy ratujący Żydów. Historie niezwykłe, Warszawa: Neriton, 2014; Janina Hera, Polacy ratujący Żydów. Słownik, Warszawa: Neriton, 2014; Sprawiedliwi i ich świat. Markowa w fotografii Józefa Ulmy, red. Mateusz Szpytma, Kraków: IPN, 2015; Polacy ratujący Żydów w czasie Zagłady. Przywracanie pamięci, Warszawa: IPN, 2016; Maria Elżbieta Szulikowska, Markowskie bociany. Opowieść o bohaterskiej rodzinie Wiktorii i Józefa Ulmów, Przemyśl: Wydawnictwo Archidiecezji Przemyskiej, 2017; Pamięć i nadzieja, Warszawa: Fundacja Lux Veritatis, 2017; Bogdan Musiał, Kto dopomoże Żydowi, współpraca Oliver Musiał, Poznań: Zysk i S-ka, 2019.

${ }^{11}$ Zob. Zagłada Żydów i stosunki polsko-żydowskie podczas II wojny światowej. Katalog publikacji 2000-2019, Warszawa: IPN, 2019, https://ipn.gov.pl/pl/publikacje/katalog-publikacji/43598,Zaglada-Zydow-i-stosunki-polsko-zydowskie-podczas-II-wojny-swiatowej-katalo g-pub.html (dostęp 14 VIII 2020 r.).

${ }^{12}$ Mam na myśli zwłaszcza zainicjowany przez Instytut Pileckiego projekt „Zawołani po imieniu”, poświęcony „osobom narodowości polskiej zamordowanym za niesienie pomocy Żydom w czasie okupacji niemieckiej", https://instytutpileckiego.pl/pl/wydarzenia/zawolani-po-imieniu (dostęp 22 X 2020 r.).

${ }^{13}$ Piotr Forecki, Po Jedwabnem. Anatomia pamięci funkcjonalnej, Warszawa 2018: IBL PAN, rozdział 3 „Rzeczpospolita Sprawiedliwych”. Zob. też: Joanna Kowalska-Leder, Wszechobecność Sprawiedliwych, „Zagłada Żydów. Studia i Materiały” 2014 nr 10, t. 2; Piotr Forecki, Anna Zawadzka, Reguła złotego środka. Kilka uwag na temat współczesnego dominującego dyskursu o „stosunkach polsko-żydowskich”, „Zagłada Żydów. Studia i Materiały” 2015, nr 11.

${ }^{14}$ Komitet został zarejestrowany jako stowarzyszenie 30 VIII $2002 \mathrm{r}$.

${ }^{15}$ Alicja Podbielska, Święta rodzina z Markowej. Kult Ulmów i polityka historyczna, „Zagłada Żydów. Studia i Materiały" 2019, nr 15.

${ }^{16}$ Ustawa z 6 III 2018 r. o ustanowieniu Narodowego Dnia Pamięci Polaków ratujących Żydów pod okupacją niemiecką, Dz.U. 2018, poz. 589. 
skandalu wywołanego niedawnym wprowadzeniem odpowiedzialności karnej za przypisywanie Polakom współodpowiedzialności za zbrodnie ludobójstwa i zbrodnie przeciwko ludzkości ${ }^{17}$.

Proces instrumentalnego wykorzystywania Sprawiedliwych i zawłaszczania pamięci o nich - również przez środowiska nacjonalistyczne - trwa nadal. W czasie gdy powstawał niniejszy artykuł, 8 sierpnia 2020 r. w Toruniu otwarto Narodowy Park Pamięci „Zachowali się jak trzeba”, stworzony dzięki państwowym dotacjom przez redemptorystę Tadeusza Rydzyka. W uroczystości otwarcia parku wzięli udział rządzący faktycznie krajem poseł Jarosław Kaczyński, premier Mateusz Morawiecki, dwaj wicepremierzy i liczne grono funkcjonariuszy publicznych. To kolejny tego rodzaju obiekt memorialny poświęcony Polakom represjonowanym za pomoc Żydom w kompleksie religijno-biznesowym toruńskiego duchownego obok otwartej w 2016 r. Kaplicy Pamięci oraz Międzynarodowego Centrum Informacyjnego „Pamięć i Tożsamość”.

Można zaryzykować twierdzenie, że po 2000 r. stawka przetargu o postawy Polaków wobec Zagłady została podbita. Skoro w przestrzeni dyskursu publicznego pojawił się problem popełnianych przez Polaków mordów na Żydach lub ich wydawania na śmierć z rąk niemieckich żandarmów czy policji granatowej, to aby go zrównoważyć, potrzebni byli już nie tylko Sprawiedliwi, którzy udzielali Żydom pomocy, ale przede wszystkim ci, którzy za to ponieśli śmierć. By odwołać się do symboli, Jedwabne trzeba było przelicytować Ulmami. Istotę tego zjawiska trafnie zdiagnozował Jacek Leociak: „Polskiemu dyskursowi o pomocy wciąż zagrażają trzy demony. Demon rywalizacji (w martyrologii, w bezinteresowności, w szlachetności); demon statystyki (liczenie tych, którzy ratowali, i tych, którzy za ratowanie zostali zabici, aby dowieźć tezy, że «im więcej, tym lepiej»); demon trywializacji (bo przecież masowość pomocy stawia pod znakiem zapytania podkreślaną wszem i wobec heroiczność czynu)"18.

W takim oto kontekście sytuacyjnym i dyskursywnym narodził się i był realizowany projekt badawczy „Indeks Polaków zamordowanych i represjonowanych za pomoc Żydom w okresie drugiej wojny światowej"19. Jego inicjatorem była krakowska fundacja Instytut Studiów Strategicznych, natomiast głównym partnerem naukowym, a z czasem głównym wykonawcą stał się Instytut Pamięci Narodowej. Na różnych etapach w realizację projektu „Indeks” były zaangażowane Naczelna Dyrekcja Archiwów Państwowych, Państwowe Muzeum Auschwitz-Birkenau, Niemiecki Instytut Historyczny w Warszawie, Żydowski

${ }^{17}$ Mowa o nowelizacji ustawy o IPN z 26 I 2018 r. (Dz.U. 2018, poz. 369). Por. Maria Babińska, Michał Bilewicz, Dominika Bulska, Agnieszka Haska, Mikołaj Winiewski, Stosunek do Żydów i ich historii po wprowadzeniu ustawy o IPN, analiza przygotowana na zlecenie Biura Rzecznika Praw Obywatelskich, Centrum Badań nad Uprzedzeniami, Warszawa 2018 (druk elektroniczny).

${ }^{18}$ Leociak, Ratowanie..., s. 9.

${ }^{19}$ Początkowo oficjalna nazwa projektu brzmiała: „INDEX Pamięci Polaków zamordowanych i represjonowanych przez hitlerowców za pomoc Żydom". 
Instytut Historyczny, Uniwersytet Papieski Jana Pawła II i Fundacja Polsko-Niemieckie Pojednanie. Punktem wyjścia tego rozpoczętego w 2005 r. projektu dokumentacyjno-edukacyjnego była hipoteza, że znane dotychczas nazwiska ofiar represji za pomoc Żydom „stanowią tylko wierzchołek góry lodowej”20.

To, że kwestia pomocy Żydom podczas Zagłady jest często wykorzystywana instrumentalnie, nie oznacza wszakże, że Sprawiedliwym nie należą się pamięć i hołd, a ich historia nie zasługuje na uczciwe badania, prowadzone sine ira et studio. Pierwsze rezultaty projektu „Indeks” prezentuje wydany w grudniu 2019 r. przez Instytut Pamięci Narodowej tom pierwszy kompendium Represje za pomoc Żydom na okupowanych ziemiach polskich w czasie II wojny światowej pod redakcją Martyny Grądzkiej-Rejak i Aleksandry Namysło ${ }^{21}$. Przystępując do jego omówienia, pragnę już na wstępie wyrazić ogólną opinię, że jest to publikacja rzeczowa i rzetelna. Jej redaktorkom naukowym i autorom poszczególnych haseł udało się (z pewnym zastrzeżeniem, o którym będzie mowa na końcu) ominąć czyhające na nich rafy i nie ulec demonom wymienionym przez Jacka Leociaka. Biorąc pod uwagę scharakteryzowane wcześniej uwarunkowania polityczne, w jakich praca powstawała, jest to osiągnięcie warte podkreślenia. Można sobie wyobrazić, z presją jakich oczekiwań, a być może i naciskami musiał mierzyć się zespół autorski ${ }^{22}$.

Zasadniczą, dokumentacyjną część książki stanowią opisy 333 przypadków niemieckich represji za pomaganie Żydom, jakie dotknęły 654 osoby. Przy czym należałoby raczej mówić o 334 przypadkach represji, gdyż w haśle poświęconym niemieckim represjom w okolicach Ciepielowa mowa w istocie o dwóch popełnionych w tym samym dniu, 6 grudnia 1942 r., zbrodniach w sąsiednich wsiach - Ciepielowie Starym (mord rodzin Kosiorów, Kowalskich i Obuchiewiczów) oraz Rekówce (mord rodziny Kosiorów i czterech innych osób). Analizując przedstawione w książce informacje, doliczyłem się również 655 ofiar repre$\mathrm{sji}^{23}$. Są to jednak korekty o drugorzędnym znaczeniu.

Poszczególne hasła mająjednolitą strukturę. Na wstępie wymieniono osoby represjonowane wraz ze wszystkimi danymi personalnymi, których ustalenie było możliwe. Dalej następuje sekcja zatytułowana „przyczyny, okoliczności i rodzaj represji”. Zwykle, jeśli źródła na to pozwalały, opis ten składa się z dwóch części: historii pomocy oraz okoliczności aktu represji sensu stricto. Noty opatrzono wy-

\footnotetext{
${ }^{20}$ Program INDEX Pamięci Polaków Zamordowanych i Represjonowanych przez Hitlerowców za Pomoc Żydom, https://www.iss.krakow.pl/program_index.php (dostęp 14 VIII 2020 r.).

${ }^{21}$ Represje za pomoc Żydom na okupowanych ziemiach polskich w czasie II wojny światowej, t. 1, red. Martyna Grądzka-Rejak, Aleksandra Namysło, IPN, Warszawa 2019, 464 s.

${ }^{22}$ Nie powinno umknąć z pola uwagi, że główny „kapłan” kultu rodziny Ulmów, pochodzący z Markowej dr Mateusz Szpytma, jest zarazem wiceprezesem Instytutu Pamięci Narodowej, nadzorującym projekt „Indeks”.

${ }^{23}$ Różnica w stosunku do podanej we wstępie liczby 654 ofiar tłumaczy się być może nieuwzględnieniem w niej sześciomiesięcznego syna Obuchowiczów z Ciepielowa Starego o nieznanym imieniu (w zbiorczym wykazie osób represjonowanych występuje jako N.N.).
} 
kazem źródeł i bibliografią. Z podpisów pod hasłami wynika, że w opracowaniu tomu wzięło udział ponad 25 autorów. Szkoda, że w książce nie zamieszczono ich listy. Hasła zaprezentowano w kolejności alfabetycznej ze względu na nazwiska osób (rodzin) represjonowanych. W pojedynczych przypadkach represji, których ofiarami były osoby o różnych nazwiskach, wymuszało to pewną arbitralność decyzji. Poruszanie się po kompendium byłoby łatwiejsze, gdyby hasła oraz niżej wspomniane zbiorcze zestawienie danych opatrzono numerami porządkowymi.

Główny korpus informacji uzupełnia tabelaryczny „Wykaz osób represjonowanych" (w istocie jest to wykaz aktów represji i osób represjonowanych w porządku odpowiadającym kolejności haseł w części opisowej). W poszczególnych rubrykach wskazano imię i nazwisko osoby represjonowanej, jej miejsce zamieszkania w dniu represji, formę udzielanej pomocy, rodzaj represji, okoliczności ujawnienia świadczonej przez nią pomocy, motywację pomocy oraz podano informację o roku ewentualnego przyznania danej osobie tytułu Sprawiedliwego wśród Narodów Świata.

Z myślą o końcowej publikacji wyników projektu „Indeks” postulowałbym uwzględnienie w tym zbiorczym wykazie informacji o wieku (względnie roku urodzenia) osób represjonowanych oraz dacie represji. Analizę informacji pod dowolnym kątem bardzo ułatwiłoby udostępnienie tego zbiorczego zestawienia w postaci elektronicznej relacyjnej bazy danych.

Do innego porządku należy postulat, aby w „Wykazie osób represjonowanych" ująć również informacje o Żydach, którzy korzystali z pomocy wymienionych tam osób, a w przypadku wykrycia pomocy najczęściej ponosili śmierć. W opisanych w książce historiach pomocy mowa łącznie o 847 ukrywanych Żydach $^{24}$. Większość z nich zginęła wraz ze swymi opiekunami. Oni też byli ofiarami tych samych aktów represji - choć nie z powodu pomocy Żydom, ale dlatego że sami byli Żydami. Informacje o żydowskich ofiarach aktów represji znajdują się w hasłach opisowych, lecz zasługują na uwzględnienie także w zestawieniu zbiorczym. Inaczej przedstawiony tam obraz rzeczywistości pozostaje niepełny, gdyż skupia się wyłącznie na nieżydowskich ofiarach. Jest to jedna z pułapek stereotypowej polskiej opowieści o pomocy, w której pomordowani (lub ocaleni) Żydzi pełnią funkcję rekwizytu, a nie równorzędnego podmiotu ${ }^{25}$.

Tom opatrzony jest aż trzema wstępami autorstwa Martyny Grądzkiej-Rejak i Aleksandry Namysło. Pierwszy, o charakterze obszernego eseju, zatytułowany jest „Relacje polsko-żydowskie w okresie II wojny światowej. Kontekst i uwarunkowania”. Drugi jest poświęcony charakterystyce projektu „Indeks”, trzeci nosi tytuł „Nota redakcyjna”. Wzajemny stosunek drugiego i trzeciego wstępu nie jest do końca klarowny; wydaje się, że podane w nich informacje o projekcie i sposobie prezentacji jego wyników mogłyby z powodzeniem zostać podane w jednym tekście.

\footnotetext{
${ }^{24}$ Represje..., s. 76.

${ }^{25}$ Podbielska, Święta rodzina z Markowej..., s. 598.
} 
Zarówno pomoc Żydom, jak i represje są pojęciami o nieostrych granicach. Kluczowe znaczenie mają więc definicje, jakimi kierowano się przy weryfikowaniu źródeł i kwalifikowaniu poszczególnych sytuacji. Na potrzeby projektu „Indeks” przyjęto, że „Pomoc to udokumentowane lub poświadczone ustnie zabronione przez prawo niemieckie świadome, czynne i pozytywne działania podjęte na rzecz wyodrębnionej niemieckim prawem ludności żydowskiej. Aby uznać dany czyn za pomoc, musi być spełniony warunek jego wymiernej efektywności, a dane działanie powinno prowadzić do konkretnego rezultatu, tj. poprawy sytuacji, w której znajdowała się osoba, zanim nadeszła pomoc. [...] Pomoc mogła być jednorazowa, krótko- lub długotrwała"26.

Definicja ta wydaje się trafna i adekwatna do obecnego stanu wiedzy o rzeczywistości okupacyjnej; jest pojemna, a zarazem wystarczająco precyzyjna i rygorystyczna. Równie wysoko ocenić wypada jakość merytoryczną i adekwatność przyjętej definicji represji: „Przez pojęcie represji rozumie się działania organów władzy wojskowej lub cywilnej III Rzeszy, w tym przede wszystkim sądów i prokuratury, organów policji i służb bezpieczeństwa przy współudziale partii nazistowskiej i jej organizacji afiliowanych i kolaboracyjnych, wobec osób, które naruszyły uregulowane okupacyjnym prawem zasady kontaktowania się z ludnością żydowską"27.

Formułując na wstępie opinię o generalnej rzetelności omawianego opracowania, mogłem się oprzeć na ogólnym wrażeniu z lektury poszczególnych haseł przefiltrowanym przez własne doświadczenie zawodowe jako historyka, nie miałem wszak możliwości skonfrontowania zamieszczonych w książce opisów z przywoływanymi źródłami. Widać jednak, że opisane przypadki pomocy i represji mieszczą się $w$ ramach przyjętych definicji, a autorzy haseł przejawiali powściągliwość w formułowaniu wniosków. Na poparcie tej tezy odwołam się do dwóch przykładów. Nie dostrzegam tendencji do mnożenia liczby osób represjonowanych. W książce uwzględniono osoby, wobec których okupant zastosował

${ }^{26}$ Represje..., s. 72 . W pominiętej w cytacie części definicji wymieniono formy pomocy: ukrywanie, organizowanie kryjówki lub pośredniczenie w jej znalezieniu; dostarczanie żywności, pieniędzy, medykamentów i odzieży ukrywającym się oraz do getta; przekazywanie korespondencji do getta i na tzw. aryjską stronę; organizowanie ucieczki z getta; organizowanie nielegalnego przerzutu za granicę; wyrabianie, organizowanie, dostarczanie fałszywych dokumentów i utrzymywanie kontaktu z żydowskim ruchem oporu. Nie jest całkiem jasne, czy autorzy definicji traktują ten katalog form pomocy jako zamknięty i tylko takie przypadki uwzględnili w pracy, czy raczej jako przykładowy.

${ }^{27}$ Represje..., s. 72. W dalszej części definicji wskazano, że pojęcie represji obejmuje: sankcje karne, cywilne i administracyjne określone w wyniku postępowania organów wymiaru sprawiedliwości; umyślne pozbawienie życia i wolności; znęcanie się fizyczne i psychiczne; pozbawienie, uszkodzenie lub zniszczenie mienia. W tym przypadku również nie jest jasne, czy autorzy definicji traktują ten katalog form represji jako wyczerpujący czy otwarty. Poprzedzający go zwrot: „W tej definicji mieszczą się następujące formy represji”, można rozumieć na oba sposoby. 
represje w sensie najbardziej bezpośrednim (doraźna egzekucja, kara śmierci, więzienie, obóz koncentracyjny, konfiskata mienia, pobicie). A przecież skutki tych represji dotykały również osierocone dzieci, owdowiałych małżonków itd. Oni też w szerokim rozumieniu byli ofiarami represji za pomaganie Żydom. Zasada podawania tylko udokumentowanych danych odnosi się także do liczby ofiar śmiertelnych represji, nieuwzględniającej osób poddanych represjom, których dalszy los nie jest szczegółowo znany, a które nie przeżyły wojny. Można więc z pewnym prawdopodobieństwem założyć, że również straciły życie w następstwie tych represji.

Drugi przykład powściągliwości autorów opracowania dotyczy kwestii przyczyn, jakie ściągnęły represje na pomagających. Jak piszą redaktorki tomu, „W 90 przypadkach spośród tych, w których udało się odtworzyć okoliczności wykrycia faktu pomocy, jego przyczyną był donos lub prawdopodobnie donos" 28 . Mamy tu chyba do czynienia z przejęzyczeniem, gdyż jak wynika z informacji podanych w zbiorczym zestawieniu osób represjonowanych, donos lub prawdopodobnie donos był przyczyną represji w 90 procentach przypadków, w których okoliczności wykrycia pomocy są znane. Odnotowano tam 105 takich przypadków, ale uważna lektura opisów okoliczności represji nasuwa przypuszczenie, że donosy były przyczyną represji w znacznie większej ich liczbie. Chodzi o sytuacje, gdy ni stąd ni zowąd w gospodarstwie wiejskim pojawiali się Niemcy i po przeprowadzeniu rewizji odnajdywali ukrywanych Żydów. Bez wyraźnego potwierdzenia w źródłach autorzy nie kwalifikowali takich przypadków represji jako spowodowanych donosem, choć okoliczności to sugerują.

W dotychczasowej literaturze przedmiotu za najbardziej miarodajną liczbę Polaków zamordowanych za pomoc udzielaną Żydom uważano liczbę 704, podaną w 1997 r. w publikacji Głównej Komisji Badania Zbrodni Hitlerowskich w Polsce ${ }^{29}$. Była to już trzecia publikacja na ten temat powstała w kręgu Głównej Komisji, oparta głównie na liczących 46 tomów aktach śledztwa prokuratora Wacława Bielawskiego. W publikacji z 1981 r. prokurator Bielawski wymienił 795 nazwisk osób, które poniosły śmierć za pomaganie Żydom, w drugim wydaniu jego pracy liczba ta wzrosła do 872 oraz 1400 osób nieznanych z nazwiska ${ }^{30}$. Raport z 1997 r. był zweryfikowaną wersją ustaleń Bielawskiego, a walor miarodajności nadawał mu autorytet głównej weryfikatorki danych, Teresy Prekerowej, autorki pionierskiej monografii „Żegoty”31.

W projekcie „Indeks” wykorzystano o wiele szerszą bazę źródłową. Oprócz akt śledczych GKBZHwP oraz Instytutu Pamięci Narodowej sięgnięto m.in. po

\footnotetext{
${ }^{28}$ Represje..., s. 77.

${ }^{29}$ Those Who Helped. Polish Rescuers of Jews During the Holocaust, red. Ryszard Walczak i in., Warszawa: IPN, 1997.

${ }^{30}$ Represje..., s. 72.

${ }^{31}$ Teresa Prekerowa, Konspiracyjna Rada Pomocy Żydom w Warszawie 1942-1945, Warszawa: PIW, 1982.
} 
dokumentację niemieckich obozów i więzień, akta niemieckich sądów okupacyjnych, raporty podziemia, akta powojennych postępowań o uznanie za zmarłego i procesów z "dekretu sierpniowego", księgi parafialne i akta stanu cywilnego, dokumentację związaną z przyznawaniem tytułu Sprawiedliwego wśród Narodów Świata, pochodzące z różnych okresów relacje. Kwerendy prowadzono w archiwach krajowych i zagranicznych.

Biorąc to wszystko pod uwagę, wydaje się niezwykle zaskakujące, że ogłoszone oficjalnie po niemal 15 latach trwania projektu „Indeks” wstępne wyniki przynoszą liczbę 341 (i pięciu prawdopodobnie) osób, które w wyniku wykrycia przez Niemców udzielanej Żydom pomocy podniosły śmierć32. Oznacza to zmniejszenie - przynajmniej na pierwszym etapie projektu - dotychczas przyjmowanej liczby ofiar niemieckich represji za pomoc Żydom o połowę!

Trzeba zarazem podkreślić, że omawiany tom zawiera nowe informacje o setkach osób prześladowanych za pomaganie Żydom, które w wyniku represji nie straciły życia i nie były uwzględniane we wcześniejszych publikacjach. Ich historie często pozostawały dotąd nieznane. Wydobycie ich na światło dzienne jest dużą wartością książki. Cenne jest również poszerzenie wiedzy o osobach, które zostały zamordowane za pomoc Żydom, nawet jeśli ich nazwiska były już znane z wcześniej ogłaszanych list represjonowanych. Taka forma owych publikacji ze swej natury na pierwszym planie stawiała bowiem liczbę ofiar, a nie ich indywidualne losy. Opowiedzenie w odniesieniu do tych przypadków historii świadczonej pomocy, opisanie okoliczności represji i ich następstw to także cenny wkład autorów kompendium.

Za poważny mankament omawianej pracy uważam natomiast brak jasnych informacji o przyjętej procedurze badawczej. We wstępie znajdujemy informację, że po zakończeniu kwerend archiwalnych sporządzono na ich podstawie bazę danych, liczącą ponad 6 tys. nazwisk osób, które m o gły być represjonowane za pomoc Żydom. Dane te podlegały dalszej „dogłębnej i skrupulatnej weryfikacji"33. Redaktorki tomu nie wyjaśniają jednak kluczowej kwestii, jaka część tych przypadków została już sprawdzona, w wyniku czego otrzymano zaprezentowany w książce zweryfikowany materiał, a jaka odrzucona ${ }^{34}$. Wzmianki na ten

${ }^{32}$ Prowizoryczne wyniki projektu ogłoszono już w 2014 r. wyłącznie w postaci publikacji elektronicznej. Odnotowano w niej 289 aktów represji wobec 508 osób. Publikacja ta nie stała się jednak przedmiotem dyskusji naukowej. Zob. Rejestr faktów represji na obywatelach polskich za pomoc ludności żydowskiej w okresie II wojny światowej, red. Aleksandra Namysło, Grzegorz Berendt, Warszawa: IPN i ISS, 2014 (druk elektroniczny).

${ }^{33}$ Represje..., s. 72.

${ }^{34}$ Nie jest też całkiem jasne, czy liczba 6 tys. rekordów w bazie danych rzeczywiście, jak sugeruje wstęp, odnosi się do nazwisk różnych osób. We wcześniejszej publikacji (Rejestr faktów represji... z 2014 r.) czytamy bowiem, że będąca podstawą tego opracowania baza danych liczyła 31 XII 2012 r. 5019 rekordów, przy czym owe rekordy odpowiadały nie osobom, lecz wykorzystanym źródłom: „Uzyskane w wyniku kwerendy dowody represji będących konsekwencją niesionej pomocy rejestrowane są w kwestionariuszach, a następnie w postaci pojedynczych 
temat są zdawkowe i niezbyt klarowne. Redaktorki deklarują, że „w pierwszej kolejności weryfikowano nazwiska najlepiej udokumentowane źródłowo"35. Czy oznacza to zatem, że - co wydawałoby się najbardziej racjonalne - najpierw dokonano wstępnego przesiewu wszystkich rekordów bazy danych, typując najlepiej udokumentowane przypadki represji, a następnie w wyniku ich skrupulatnej weryfikacji uzyskano liczbę 654 potwierdzonych ofiar represji? Czy może weryfikacja objęła tylko część rekordów bazy danych, a jeśli tak, to jaką i na podstawie jakich kryteriów wybraną?

Niewyjaśnienie kwestii metodologii badań utrudnia poszukiwanie odpowiedzi na narzucające się pytanie, jak opisane w książce 333 przypadki represji mają się - przynajmniej w sensie liczbowym - do całości badanego zjawiska. Czy można się pokusić o ekstrapolację (i na jakiej zasadzie) opublikowanych danych, by oszacować możliwą całkowitą liczbę represjonowanych? Jeśli przyjąć założenie, że weryfikacja w pierwszej kolejności najlepiej udokumentowanych przypadków przyniosła dane o 654 ofiarach represji za pomoc Żydom (w tym 341 ofiarach śmiertelnych), wydaje się mało prawdopodobne, by po sfinalizowaniu projektu „Indeks”, a zatem po zweryfikowaniu słabiej udokumentowanej części przypadków liczby te mogły wzrosnąć więcej niż dwukrotnie.

Inna interesująca kwestia, do której niestety nie odniosły się autorki wstępu, dotyczy tego, jak w świetle przeprowadzonych w ramach projektu „Indeks” procedur weryfikacyjnych prezentuje się jakość wcześniejszych ustaleń, których wyniki przedstawiano w publikacjach Głównej Komisji. Z mojego pobieżnego porównania wynika, że aż 69 procent nazwisk wymienionych w raporcie Those who helped... z 1997 r. w ogóle nie pojawia się w omawianej tu publikacji IPN. Nieco światła na tę sprawę rzuca wypowiedź jednej z redaktorek tomu podczas spotkania promocyjnego, że w toku weryfikacji materiałów akt śledztwa prokuratora Bielawskiego, za co zabrano się w pierwszej kolejności, w wielu przypadkach okazywało się, iż udokumentowane tam akty represji w ogóle nie miały związku z pomocą dla Żydów ${ }^{36}$.

Omawiany tom przynosi bogactwo szczegółowych informacji o niemieckich represjach za pomaganie Żydom. Są one wiarygodne i dobrze udokumentowane, ale czytelnik zostaje pozostawiony z nimi sam. Redaktorki nie podejmują próby odpowiedzi na pytanie, co z tego wszystkiego wynika. Z wyjątkiem kilku uwag dotyczących liczby osób represjonowanych i rodzajów represji nie dokonują analizy zgromadzonych danych.

rekordów umieszczane w komputerowej bazie danych. [...] Każdy kwestionariusz sporządzany jest na podstawie analizy jednego źródła (jednostki archiwalnej, materiału prasowego, publikacji książkowej), dlatego też jedna osoba lub jeden przypadek represji może pojawić się w kilku kwestionariuszach (rekordach), a co za tym idzie liczba rekordów nie odpowiada liczbie przypadków represji”. Wynikałoby z tego, że w bazie danych nazwiska osób, które mogły być represjonowane, powtarzają się, toteż ich liczba jest mniejsza od liczby rekordów.

${ }^{35}$ Represje..., s. 73.

${ }^{36}$ Notatki własne ze spotkania 16 I $2020 \mathrm{r}$. 
Domyślam się, że redaktorki uchyliły się od interpretacji zebranych informacji, gdyż publikacja prezentuje wstępne, częściowe wyniki projektu badawczego. Same piszą, że „[z]amieszczone w tomie 333 noty nie mogą stanowić grupy reprezentatywnej dla całości zebranego materiału w ramach projektu «Indeks»" ${ }^{37}$. Inna rzecz, że w świetle nieklarownych wyjaśnień o procedurze badawczej nie ma podstaw, by orzec ani o reprezentatywności, ani o niereprezentatywności opisanych w książce przypadków. Tego po prostu nie wiemy.

Mimo to sądzę, że warto - ze świadomością, że poniższe analizy i wnioski mają charakter prowizoryczny i będą musiały być powtórzone po opublikowaniu finalnych wyników projektu „Indeks” - już teraz pokusić się o bliższe przyjrzenie się, choćby pod kątem ilościowym, opisanym w tomie przypadkom represji. Dotyczy to zwłaszcza tych wskaźników, co do których na podstawie ogólnej wiedzy o realiach Zagłady można się spodziewać, że ich rozkład i proporcje nie powinny się radykalnie zmienić.

Za taką próbą podsumowania obecnego stanu wiedzy przemawiają dwa powody. Po pierwsze, tego rodzaju pytania i tak będą stawiane ze względu na znaczenie problematyki pomocy Żydom, a w szczególności rolę argumentu z liczby represjonowanych w debacie publicznej. Po wtóre, nie wiadomo, kiedy można się spodziewać ogłoszenia finalnych wyników projektu „Indeks”. Na pierwsze rezultaty trzeba było czekać aż 14 lat ${ }^{38}$. Tymczasem w ostatnim okresie aktywność Instytutu Pamięci Narodowej, jeśli chodzi o problematykę Zagłady, w znacznej mierze skupiała się - ze szkodą dla badań podstawowych - raczej na polemice $\mathrm{z}$ innymi badaczami, prezentującymi odmienny od oficjalnie pożądanego obraz postaw Polaków wobec Żydów ${ }^{39}$.

A zatem kto, kiedy, gdzie, za jakie czyny, w jaki sposób był represjonowany w związku z pomocą udzielaną Żydom i jakie były skutki tych represji? Redaktorki tomu podają, że w 333 opisanych przypadkach różnego rodzaju represje dotknęły 654 osoby, z których 341 (i pięć prawdopodobnie) poniosło śmierć. Aż 258 osób zostało zabitych w momencie wykrycia pomocy lub niedługo potem, na 22 (i dwóch prawdopodobnie) wykonano wyroki śmierci, 61 zmarło w więzieniach i obozach koncentracyjnych. W sumie do więzień i obozów trafiły

\footnotetext{
${ }^{37}$ Represje..., s. 76, przypis 3.
}

${ }^{38}$ W 2008 r. koordynator naukowy projektu „Indeks” Grzegorz Berendt deklarował, że pierwszy tom leksykonu Polaków represjonowanych za pomaganie Żydom ukaże się w połowie 2009 r. (Ewa Czaczkowska, Uratujmy pamięć Sprawiedliwych, „Rzeczpospolita”, 27 V 2008).

${ }^{39}$ Mam na myśli udział niektórych historyków z IPN w nagonce przeciwko autorom pracy Dalej jest noc. Losy Żydów w wybranych powiatach okupowanej Polski. Zob. Tomasz Domański, Korekta obrazu? Refleksje źródłoznawcze wokół książki „Dalej jest noc. Losy Żydów w wybranych powiatach okupowanej Polski”, Warszawa: IPN, 2019; idem, Korekty ciąg dalszy, Warszawa: IPN, 2020. Por. Nieudana korekta obrazu. Odpowiedzi redaktorów tomów oraz autorów poszczególnych rozdziałów na broszurę autorstwa dr. Tomasza Domańskiego, http://www.holocaustresearch.pl/index.php?show=555 (dostęp 14 VIII 2020 r.). 
344 osoby. Kilkadziesiąt osób było aresztowanych na krótszy czas, wysłano je na roboty przymusowe, pobito lub skonfiskowano ich mienie ${ }^{40}$.

Dane te są powodem kolejnego zaskoczenia. Okazuje się bowiem, że wbrew utrwalonej obiegowej opinii, a także wbrew literalnemu brzmieniu rozporządzenia generalnego gubernatora Hansa Franka z 15 października 1941 r. wprowadzającego karę śmierci dla osób, które udzielały schronienia Żydom przebywającym bez upoważnienia poza gettem ${ }^{41}$ (co powtarzały późniejsze zarządzenia gubernatorów poszczególnych dystryktów GG), wykrycie pomocy Żydom nie zawsze kończyło się doraźną egzekucją jej udzielających. Już samo to, że nierzadko byli stawiani przed sądem, a nie zabijani bez sądu, jest faktem mało znanym, a w każdym razie nie funkcjonuje w potocznej świadomości historycznej. Co więcej, w przypadku 16 osób skazanych na śmierć kara ta została zamieniona na więzienie w drodze aktu łaski generalnego gubernatora Franka ${ }^{42}$. Statystycznie rzecz ujmując, na 654 represjonowane osoby śmierć wyniku represji poniosło 52 procent, $w$ tym 39 procent $w$ doraźnej egzekucji lub wkrótce po tym, jak władze okupacyjne wykryły udzielanie pomocy.

Wysnuwanie na tej podstawie wniosku, że pomoc dla Żydów nie była „aż tak” ryzykowna, byłoby jednak pochopne i niezasadne. Nikt, kto pomagał Żydom, nie mógł mieć pewności, jaka sankcja ze strony okupanta może go spotkać. Zgromadzone w tomie informacje o represjach wskazują na całkowitą arbitralność niemieckich reakcji na wykrycie pomocy Żydom. Wreszcie nawet statystyczne prawdopodobieństwo śmierci wynoszące około 1/2 oznacza, że pomaganie Żydom niosło ze sobą olbrzymie ryzyko.

Warto bliżej przyjrzeć się rodzajom represji i ich śmiertelnym skutkom. Zaznaczam, że moje wyliczenia dokonane na podstawie zamieszczonego w książce zbiorczego wykazu osób represjonowanych, przedstawione w tabeli 1, różnią się minimalnie od liczb podanych przez redaktorki tomu we wstępie. Wynika to $\mathrm{z}$ odmiennego zakwalifikowania pojedynczych przypadków represji, lecz nie zmienia ich całościowego obrazu.

Zgromadzone dane w pełni potwierdzają, że represje za pomoc Żydom były bardzo surowe. Śmierć poniosło lub prawdopodobnie poniosło 53 procent represjonowanych osób, z czego 39 procent w wyniku doraźnej egzekucji lub mordu dokonanego niedługo po wykryciu pomocy. Jeśli weźmiemy również pod uwagę kilka osób, którym udało się przeżyć egzekucję, osoby wobec których orzeczono karę śmierci, ale jej nie wykonano, i osoby zesłane do obozów koncentracyjnych, gdzie śmiertelność była bardzo wysoka, to okaże się, że aż $2 / 3$ represjonowanych osób Niemcy chcieli zabić lub zastosowali wobec nich sankcje narażające je na

\footnotetext{
${ }^{40}$ Represje..., s. 77.

${ }^{41}$ Eksterminacja Żydów na ziemiach polskich $w$ okresie okupacji hitlerowskiej. Zbiór dokumentów, red. Tatiana Berenstein, Artur Eisenbach, Adam Rutkowski, Warszawa: ŻIH, 1957, s. $122-123$.

${ }^{42}$ Represje..., s. 77.
} 
Tabela 1. Formy i następstwa represji za pomoc Żydom

\begin{tabular}{|l|r|r|r|r|r|r|}
\hline \multirow{2}{*}{ Forma represji } & \multicolumn{2}{|c|}{$\begin{array}{c}\text { Śmierć osoby } \\
\text { represjonowanej }\end{array}$} & \multicolumn{2}{c|}{$\begin{array}{c}\text { Brak informacji } \\
\text { o śmierci osoby } \\
\text { represjonowanej }\end{array}$} & \multicolumn{2}{|c|}{$\begin{array}{c}\text { Razem osób } \\
\text { represjonowa- } \\
\text { nych }\end{array}$} \\
\cline { 2 - 7 } & liczba & odsetek & liczba & odsetek & liczba & odsetek \\
\hline $\begin{array}{l}\text { Egzekucja doraźna } \\
\text { lub śmierć wkrótce } \\
\text { po wykryciu pomocy }\end{array}$ & 258 & $39 \%$ & $3^{\text {a }}$ & $0 \%$ & 261 & $40 \%$ \\
\hline Kara śmierci & 21 & $3 \%$ & 30 & $5 \%$ & 51 & $8 \%$ \\
\hline Obóz koncentracyjny & 48 & $7 \%$ & 55 & $8 \%$ & 103 & $16 \%$ \\
\hline Więzienie & 15 & $2 \%$ & 96 & $15 \%$ & 111 & $17 \%$ \\
\hline Areszt krótkotrwały & - & - & 64 & $10 \%$ & 94 & $10 \%$ \\
\hline Inne represje & - & - & 57 & $9 \%$ & 57 & $9 \%$ \\
\hline Prawdopodobnie śmierć & 8 & $1 \%$ & - & $0 \%$ & 8 & $1 \%$ \\
\hline Razem & $\mathbf{3 5 0}$ & $\mathbf{5 3 \%}$ & $\mathbf{3 0 5}$ & $\mathbf{4 7 \%}$ & $\mathbf{6 5 5}$ & $\mathbf{1 0 0 \%}$ \\
\hline
\end{tabular}

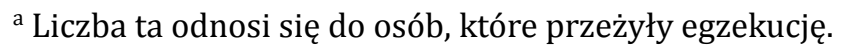

wysokie prawdopodobieństwo utraty życia (nie uwzględniam w tej liczbie osób, które trafiły do więzień, z których 14 procent zmarło). Paradoksalnie w opisanych w książce przypadkach represji skazani na śmierć przez okupacyjne sądy mieli statystycznie większą szansę przeżycia niż zesłani do obozów koncentracyjnych. Tylko wobec $1 / 5$ osób pomagających Żydom zastosowano lżejsze formy represji, w tym krótkotrwały areszt.

Stosując najcięższe represje, Niemcy nie czynili wyjątków wobec kobiet. Stanowiły one 41 procent ogółu represjonowanych (269 osób), a wśród osób zabitych w bezpośrednim następstwie wykrycia pomocy - 42 procent. Dopiero wśród zmarłych w więzieniach i obozach odsetek kobiet jest niższy (29 procent), co tłumaczy się zapewne tym, że relatywnie rzadziej były zsyłane do obozów koncentracyjnych (gdzie z kolei prawdopodobieństwo śmierci było wyższe niż w więzieniu). Niestety, zamieszczony w książce zbiorczy wykaz osób represjonowanych nie pozwala stwierdzić, jaką część z nich stanowiły dzieci.

$\mathrm{Na}$ kwestię ryzyka, z jakim wiązało się udzielanie Żydom pomocy, można spojrzeć również przez pryzmat statystyki aktów represji. Trzeba bowiem pamiętać, że Niemcy stosowali odpowiedzialność zbiorową i często w razie wykrycia pomocy Żydom represje dotykały kilku zaangażowanych w nią osób lub członków ich rodzin. W połowie opisanych w książce przypadków (167 z 333) represje pociągnęły za sobą śmierć przynajmniej jednej osoby.

Stereotypowa opowieść o represjach wobec Sprawiedliwych mówi, że w przypadku wykrycia pomocy Żydom śmierć czekała całą rodzinę ratujących. 
Emblematycznymi przykładami są zamordowane rodziny Baranków, Kowalskich czy Ulmów ${ }^{43}$. Podobnych mordów rodzin zidentyfikowano w kompendium jeszcze kilka (m.in. rodziny Deców, Książków i Kucharskich, Olszewskich, Rębisiów, Wołowców), na szczęście należały do wyjątków ${ }^{44}$. W 106 opisanych przypadkach represji (32 procent) zginęła lub zmarła jedna osoba, w 36 przypadkach (11 procent) - 2 osoby, w 10 przypadkach (3 procent) - 3 osoby, a w 15 przypadkach (5 procent) - 4 lub więcej osób. Największa (i wyjątkowa) liczba ofiar pojedynczego mordu za pomoc Żydom to $21 \mathrm{w}$ Ciepielowie Starym; kolejna liczba w tym szeregu to 12 . Rozkład całkowitej liczby osób represjonowanych (nie tylko tych, które poniosły śmierć) przedstawia wykres 1. W 60 procentach przypadków różnego rodzaju represje dotknęły jedną osobę, w 22 procentach przypadków - 2 osoby, w 10 procentach przypadków - 3 osoby, w 4 procentach przypadków - 4 osoby i w 6 procentach przypadków - 5 lub więcej osób.

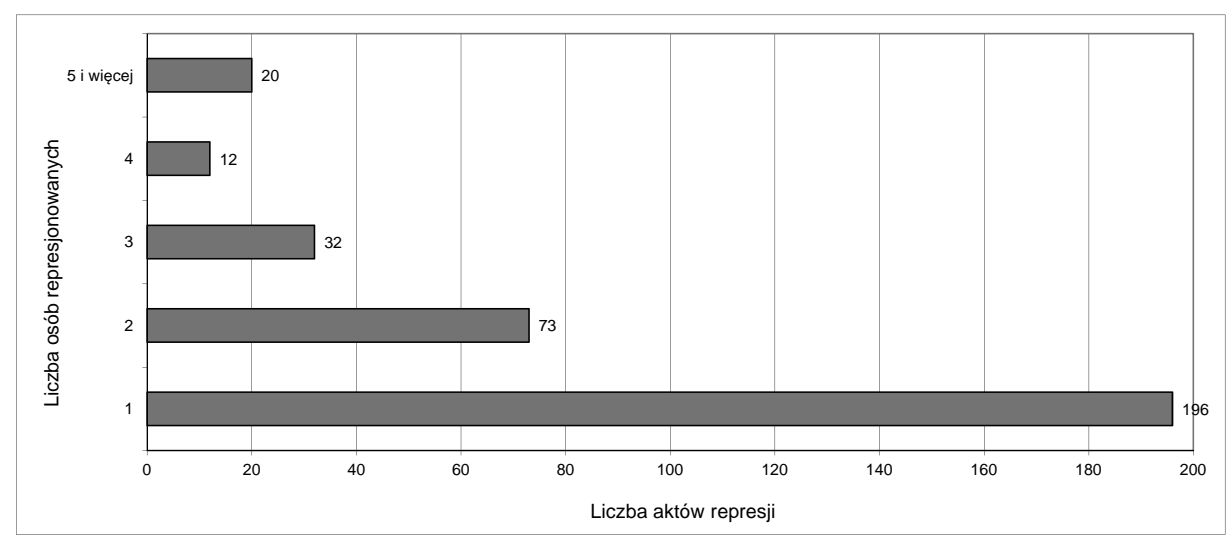

Wykres 1. Rozkład liczby osób represjonowanych

Jak podają redaktorki tomu, większość (około 70 procent) opisanych historii pomocy polegało na ukrywaniu Żydów lub zaangażowaniu w zapewnienie im schronienia ${ }^{45}$. Jak wcześniej wspomniano, jeśli w źródłach zostały mniej lub bardziej precyzyjnie udokumentowane okoliczności, w jakich doszło do ujawnienia wobec okupanta tej pomocy, to był to prawie zawsze donos. W 22 przypadkach pomagający byli represjonowani wskutek wskazania ich przez Żydów, którzy wpadli w ręce policji granatowej lub niemieckiej żandarmerii, osób, które

\footnotetext{
${ }^{43}$ Represje..., s. 94-105, 190-192, 324-325.

${ }^{44}$ Ibidem, s. 201-204, 214-215, 252-253, 278-280, 338-339.

${ }^{45}$ Ibidem, s. 76.
} 
im pomagały ${ }^{46}$. Zwykle poddawano ich brutalnym przesłuchaniom, by wydobyć informacje o innych ukrywających się Żydach, ukrytym majątku i osobach, z których pomocy korzystali ${ }^{47}$. W 20 innych przypadkach represje nastąpiły wskutek zbiegu okoliczności albo niezachowania ostrożności przez niosących pomoc lub ukrywanych.

Chociaż tytuł projektu „Indeks” mówi o Polakach represjonowanych za pomoc Żydom, badania - słusznie - uwzględniają obywateli polskich różnych narodowości zamieszkałych na terytorium Rzeczypospolitej w przedwojennych granicach. Aczkolwiek z zastrzeżeniem, że chodzi o osoby „nieobjęte ustawodawstwem norymberskim"48. Taka decyzja rodzi być może nie tylko teoretyczny problem, jak traktować Żydów żyjących na „aryjskich papierach”, którzy - jako Polacy - mogli stać się ofiarami represji za pomaganie innym Żydom. Nie wiem, czy takie przypadki już udokumentowano w ramach projektu, warto jednak rozważyć tę kwestię z myślą o kolejnych tomach kompendium ${ }^{49}$. Badania ostatnich lat w coraz większym stopniu pokazują, że Żydzi nie byli tylko biernymi beneficjentami pomocy świadczonej przez chrześcijan, lecz także sami ją organizowali $^{50}$. Tak czy inaczej olbrzymia większość wymienionych w kompendium osób to Polacy, co wynika głównie z rozkładu geograficznego opisanych przypadków represji. Wśród represjonowanych pojawia się też kilkoro Ukraińców, a nawet Niemcy - przedwojenni obywatele polscy i Volksdeutsch ${ }^{51}$.

${ }^{46} \mathrm{O}$ roli policji granatowej w Zagładzie, w tym w stosowaniu represji wobec pomagających Żydom, zob. Grabowski, Na posterunku...

${ }^{47}$ Notatki własne ze spotkania 16 I 2020 r. Problem obaw ratujących przed zadenuncjowaniem ich przez Żydów, którym wcześniej pomagali, porusza Tomasz Frydel, Powiat dębicki, w: Dalej jest noc..., t. 2, s. 456-464.

${ }^{48}$ Represje..., s. 72.

${ }^{49}$ Niewykuczone, że ukrywającymi się Żydami byli Wincenty i Anna Buzowiczowie, o których mowa na s. 112-113 kompendium, straceni w 1943 r. za udzielenie dwóm Żydówkom pomocy w ucieczce z getta w Kozienicach. Może na to wskazywać fakt, że po wojnie Lejb Majzels, zajmujący się na zlecenie CKŻP poszukiwaniem dzieci żydowskich pozostających w rodzinach polskich, podejmował próby odzyskania córki Buzowiczów znajdującej się u Józefa Wójcika (Archiwum Żydowskiego Instytutu Historycznego, 303/IX/17, Notatka L. Majzelsa z delegacji do Kozienic, 14 VIII 1948 r.). Za udostępnienie kopii tego dokumentu dziękuję Annie Bikont, która przygotowuje książkę o poszukiwaniu dzieci żydowskich w Polsce po wojnie.

${ }^{50}$ Barbara Engelking, Żydzi pomagający innym Żydom $w$ ukrywaniu się po aryjskiej stronie $w$ Warszawie [w:] Żydzi w walce z nazistowskimi Niemcami podczas drugiej wojny światowej, red. Krzysztof Persak (w przygotowaniu). O skali pomocy organizowanej przez Żydowski Komitet Narodowy i Bund, znacznie przewyższającej swoim zasięgiem sieć pomocową „Żegoty”, pisał Marcin Urynowicz (idem, Zorganizowana i indywidualana pomoc Polaków dla ludności żydowskiej eksterminowanej przez okupanta niemieckiego w okresie drugiej wojny światowej [w:] Polacy i Żydzi pod okupacjq niemieckq 1939-1945...). Zob. też Anna Bikont, Żegota jako organizacja Żydów i Polaków, w: Żydzi w walce z nazistowskimi Niemcami...

${ }^{51}$ Wśród represjonowanych warto odnotować także dwóch policjantów granatowych. 
Zdecydowana większość historii represji opisanych w książce $(279$, tj. 84 procent) rozegrała się $\mathrm{w}$ Generalnym Gubernatorstwie ${ }^{52}, 44$ na terenach wcielonych do Rzeszy (w tym 20 w okręgu Białystok) i 10 na terenie tzw. Ostlandu. Bez wątpienia taka geograficzna dystrybucja opisanych przypadków nie daje podstaw do wyciągania ogólnych wniosków o zjawisku pomocy Żydom i represji, jest bowiem ewidentnie funkcją dostępności i kompletności bazy źródłowej. Wypada więc stwierdzić, że o represjach za pomaganie Żydom na Wschodzie nie wiemy prawie nic. Jeżeli zaś chodzi o Generalne Gubernatorstwo, pewną zagadką wydaje się dysproporcjonalnie mała liczba udokumentowanych - jak dotąd - przypadków z dystryktu lubelskiego. Gdy mowa o geografii, należy wytknąć brak w omawianej publikacji indeksu miejscowości, który w tego rodzaju kompendium jest po prostu niezbędny.

Kazusy opisane w książce odnoszą się głównie do rzeczywistości wsi i mniejszych miast. W największych miastach GG odnotowano łącznie 47 przypadków represji ( $20 \mathrm{w}$ Warszawie, 13 we Lwowie, $14 \mathrm{w}$ Krakowie). Jest to z pewnością zbyt mała próbka, by pokusić się o wnioskowanie, czy pomaganie Żydom w środowisku wielkomiejskim niosło mniejsze ryzyko. Warto jednak tytułem pytania badawczego zwrócić uwagę, że represje we wspomnianych metropoliach pociągnęły za sobą śmierć pomagających Żydom w $1 / 5$ przypadków, podczas gdy dla całego przedstawionego w książce spektrum sytuacji wskaźnik ten wynosił 1/2.

0 ile kwestia ogólnej reprezentatywności przedstawionych w omawianej publikacji przypadków represji za pomoc Żydom pozostaje otwarta, o tyle ich rozkład chronologiczny jest wyraźnie zgodny z wiedzą o przebiegu zagłady Żydów polskich. Jeśli za miarę dynamiki Zagłady przyjąć dane o deportacjach z likwidowanych gett do obozów śmierci, to apogeum mordu przypadło na lato i jesień 1942 r. Od lipca (początek likwidacji getta warszawskiego) do listopada 1942 r. Niemcy deportowali do obozów zagłady około 1,2 mln Żydów polskich, a do lutego 1943 r. (zakończenie akcji „Reinhardt” w okręgu białostockim) ponad 1,3 mln, czyli około trzech czwartych polskich ofiar obozów zagłady ${ }^{53}$. Również apogeum represji za pomoc udzielaną Żydom przypadło na okres od czwartego kwartału 1942 do końca pierwszego kwartału 1943 r. Wydarzyła się

${ }^{52}$ Dystrykt radomski - 105, krakowski - 84, warszawski - 39, galicyjski - 35, lubelski 16 przypadków.

${ }^{53}$ Oszacowanie obejmujące deportacje do obozów akcji „Reinhardt” oraz trwające równolegle deportacje do Chełmna nad Nerem i Auschwitz na podstawie: Patrick Montague, Chełmno. Pierwszy nazistowski obóz zagłady, tłum. Tomasz S. Gałązka, Wołowiec: Czarne, 2014; Robert Kuwałek, Obóz zagłady w Bełżcu, Lublin: Państwowe Muzeum na Majdanku, 2010; idem, Nowe ustalenia dotycząe liczby ofiar niemieckiego obozu zagłady w Sobiborze, „Zeszyty Majdanka" 2014, nr 26, s. 17-60; Tomasz Kranz, Zagłada Żydów w obozie koncentracyjnym na Majdanku, Lublin: Państwowe Muzeum na Majdanku, 2010; Yitzhak Arad, The Operation Reinhard Death Camps. Belzec, Sobibor, Treblinka. Revised and Expanded Edition, Bloomington: Indiana University Press, 2018; Franciszek Piper, Ilu ludzi zginęło w KL Auschwitz, Oświęcim: Wydawnictwo Państwowego Muzeum w Oświęcimiu, 1992. 
wówczas połowa opisanych w omawianej pracy przypadków represji. Pierwsze odnotowane doraźne egzekucje na wsi za pomoc Żydom zostały przeprowadzone w połowie września $1942 \mathrm{r}$.

Większość aktów represji daje się datować z dokładnością co do dnia, miesiąca lub przynajmniej pory roku, aczkolwiek w źródłach, zwłaszcza relacjach i zeznaniach świadków, zdarzają się błędy w datacji, polegające na przesunięciu danego faktu o rok lub dwa. W przypadku kilku haseł realia historyczne wskazują, że opisane wydarzenia najprawdopodobniej zaszły nie w 1941 lub wiosną 1942 r., lecz raczej w 1943 r. Z uwzględnieniem tych korekt można podjąć próbę zilustrowania na wykresie 2 dynamiki opisanych $w$ książce niemieckich represji za pomaganie Żydom.

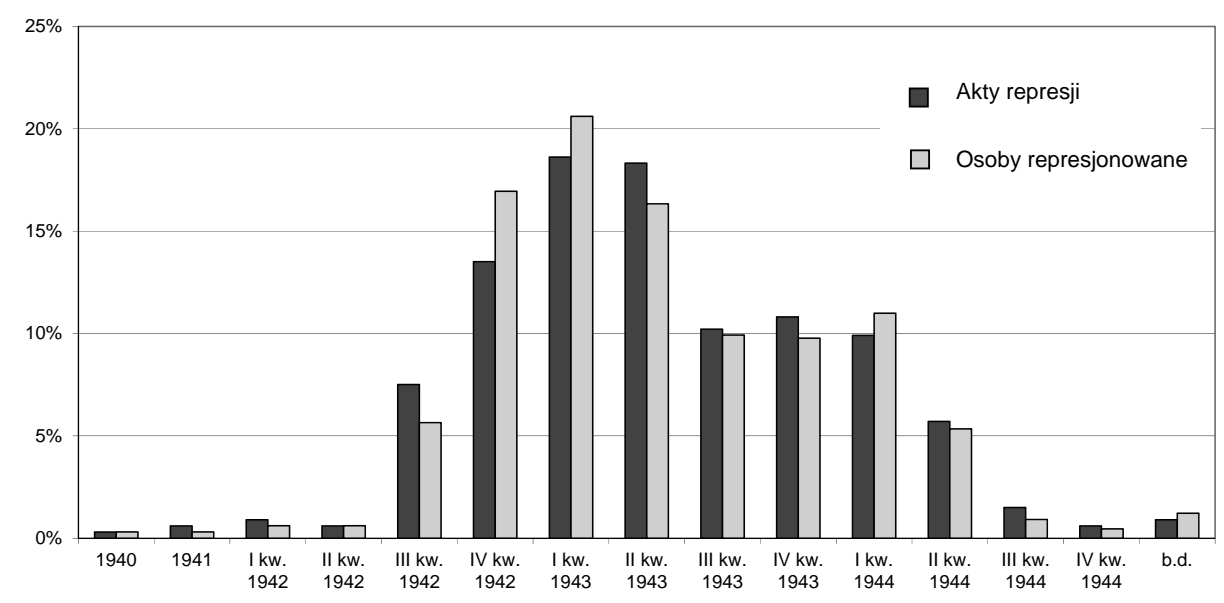

Wykres 2. Dynamika represji za pomoc Żydom

Przedstawiony w książce dramat - mordy ukrywających się Żydów i represje wobec udzielających im pomocy chrześcijan - rozegrał się w zasadzie w ciągu półtora roku: od jesieni 1942 do wiosny 1944 r. Na ten okres przypada około 90 procent odnotowanych aktów represji. Początkową cezurę czasową wyznacza moment intensyfikacji akcji „Reinhard”, natomiast wygasanie represji za pomoc Żydom wiosną 1944 r. tłumaczy się być może tym, że do tego czasu większość Żydów, którzy w okresie likwidacji gett poszukiwali ratunku wśród chrześcijan, po prostu już nie żyła ${ }^{54}$.

${ }^{54}$ Dodatkowym czynnikiem wyjaśniającym mogłoby być wyzwolenie na początku $1944 \mathrm{r}$. części terytorium Polski spod okupacji niemieckiej, nie odnosi się to jednak do obszaru, z którego pochodzi większość udokumentowanych w książce przypadków represji (dystrykty radomski i krakowski GG). 
Na koniec omówienia części dokumentacyjnej książki wypada zwrócić uwagę na pewną niespójność między jej tytułem Represje za pomoc Żydom na okupowanych ziemiach polskich a przyjętą na potrzeby projektu „Indeks” definicją represji, z której wynika, że przedmiotem badań są represyjne działania „organów władzy wojskowej i cywilnej III Rzeszy”. Niespójność ta wytwarza pewną lukę, w której kryją się przypadki represjonowania Polaków... przez innych Polaków za pomaganie Żydom.

Badania prowadzone w ostatnich latach przynoszą coraz więcej informacji o przypadkach zabijania ukrywających się Żydów przez polskie formacje podziemne spod różnych znaków. Wrogość wobec Żydów przenoszona była także na tych, którzy im pomagali. Podczas dokonywanych przez partyzantów rewizji w poszukiwaniu ukrywanych Żydów nierzadko dochodziło do brutalnego bicia polskich gospodarzy. W listopadzie 1943 r. w Stawisku koło Klimontowa członkowie NSZ pobili Marię Stojek, podejrzewali ją bowiem o przechowywanie dwóch Żydów. Bracia Marian i Henryk Stąporowscy, ukrywający w Bogorii Skotnickiej rodzinę Nutów, zostali w grudniu 1943 r. pobici przez członków Ludowej Straży Bezpieczeństwa Batalionów Chłopskich. Również bechowcy w tym samym czasie pobili Wawrzyńca Florasa, który w Krzcinie niedaleko Sandomierza ukrywał braci Zobermanów. Józefę Ziółkowską z Opoczna ukrywającą Abrama Rabinowicza i Szlomę Lewkowicza pobili w styczniu 1944 r. partyzanci NSZ. Podobny los ze strony tej samej organizacji podziemnej spotkał w maju $1944 \mathrm{r}$. Józefa Łubowskiego, który w Adamowie, gmina Machory, ukrywał rodzinę Birencwajgów. Stefana Krakowiaka z Dmosic koło Klimontowa w lutym 1943 r. akowcy nie tylko pobili, ale nałożyli na niego kontrybucję za zadawanie się z Żydami ${ }^{55}$. W Chrząstowie, powiat Dębica, w maju 1944 r. partyzanci AK pobili Szymona Korczaka, który ukrywał rodzinę Verstandigów, i także nałożyli na niego karę pieniężną ${ }^{56}$. We wszystkich tych przypadkach partyzanci zabili szukających ratunku Żydów. Zdarzało się jednak również, że wraz z Żydami ofiarami mordu padali ich polscy opiekunowie. W lutym 1944 r. partyzanci z oddziału AK Mariana Sołtysiaka „Barabasza” zamordowali w Zagórzu pod Daleszycami Stefana Sawę wraz z ukrywanymi przez niego członkami rodziny Zelingerów ${ }^{57}$. Trzy miesiące później w Giebułtowie w powiecie miechowskim oddział NSZ zabił jedenaście osób z rodzin Herszkowiczów, Matuszyńskich i Lejzorków oraz żonę i córkę Józefa Koniecznego, u którego Żydzi się ukrywali ${ }^{58}$.

Większość przytoczonych przykładów pochodzi z badań dotyczących Kielecczyzny, nie ma jednak powodu zakładać, by tego rodzaju zbrodnie stanowiły wy-

${ }^{55}$ Joanna Tokarska-Bakir, Bracia miesiące. Studia z antropologii historycznej Polski 19391946 (w druku).

${ }^{56}$ Frydel, Powiat dębicki..., s. 441.

${ }^{57}$ Alina Skibińska, Joanna Tokarska-Bakir, Barabasz i Żydzi. Z historii oddziału AK,Wybranieccy”, „Zagłada Żydów. Studia i Materiały” 2011, nr 7, s. 91-104.

${ }^{58}$ Dariusz Libionka, Powiat miechowski [w:] Dalej jest noc..., t. 2, s. 188-189; Tokarska-Bakir, Bracia miesiące... 
jątek na tle okupowanego kraju ${ }^{59}$. To również były represje - choć nie niemieckie - wobec Polaków za pomoc Żydom. I nie powinny umykać z pola widzenia.

Ratujący Żydów mieli więc powody, by obawiać się nie tylko donosu do Niemców - o czym jednoznacznie powiedziano w omawianej pracy - lecz także bezpośredniej agresji ze strony polskiego otoczenia. 0 tym też trzeba pamiętać, gdy rozważa się kwestię ryzyka, z jakim wiązało się pomaganie Żydom. Akty przemocy wobec Sprawiedliwych ze strony niepodległościowego podziemia, mające chyba charakter swoistej zemsty za udzielanie Żydom pomocy, zdarzały się zresztą jeszcze po wojnie. Dość przywołać znany przypadek pobicia w marcu 1945 r. przez członków poakowskiego podziemia Antoniny Wyrzykowskiej, która od listopada 1942 do wyzwolenia w styczniu 1945 r. ukrywała w Janczewku koło Jedwabnego siedmioro Żydów ${ }^{60}$. Również Stanisław Sobczak z Frampola na Lubelszczyźnie, który od jesieni 1942 r. do końca okupacji przechowywał u siebie 12 osób, został po wyzwoleniu okrutnie pobity i obrabowany przez partyzantów ${ }^{61}$.

Za najmniej udaną część omawianej książki uważam esej wstępny „Relacje polsko-żydowskie w okresie II wojny światowej. Kontekst i uwarunkowania”. Nie chodzi tu nawet o merytoryczne aspekty tego tekstu, bo nie ma w nim istotnych błędów faktograficznych, ale bardziej o jego konstrukcję, sposób argumentacji, obfitujący w niedomówienia i uniki język, wreszcie o funkcję, jaką ów esej zdaje się pełnić. 0 ile autorom pracy udało się w części dokumentacyjnej nie ugiąć się pod presją oczekiwań i uniknąć świadczenia serwitutów na rzecz oficjalnej polityki historycznej, o tyle jako taki właśnie serwitut odbieram esej wstępny.

Niejako na marginesie warto zwrócić uwagę na pewną nieadekwatność zarówno w odniesieniu do okresu przedwojennego, jak i do czasów Zagłady pojęcia „relacje” czy „stosunki” polsko-żydowskie, które niesie w sobie sugestię symetrii i równorzędnej pozycji "stron” takich stosunków. Przed wojną mieliśmy raczej do czynienia z dominującą większością i dyskryminowaną mniejszością, podczas wojny zaś - zwłaszcza w okresie od 1942 r., o którym traktuje zasadnicza część pracy - z grupą poddaną bezwzględnemu terrorowi oraz grupą, której Niemcy w ogóle odmówili prawa do istnienia. Z posłużenia się kategorią relacji polsko-żydowskich nie czynię jednak autorkom zarzutu. Przy wszystkich zastrzeżeniach, jakimi należałoby je opatrzyć, pojęcie to zakorzeniło się $\mathrm{w}$ dyskursie historycznym i zapewne trudno będzie znaleźć dla niego określenie alternatywne. W końcu sam Emanuel Ringelblum użył go w tytule swojego pisanego w ukryciu dzieła ${ }^{62}$. Posługując się nim, warto jednak mieć na

${ }^{59}$ Zob. Aleksandra Bańkowska, Partyzantka polska z lat 1942-1944 w relacjach żydowskich, „Zagłada Żydów. Studia i Materiały” 2005, nr 1.

${ }^{60}$ Anna Bikont, My z Jedwabnego, wyd. 2, Wołowiec: Czarne, 2012, s. 381.

${ }^{61}$ Alina Skibińska, Powiat biłgorajski [w:] Dalej jest noc..., t. 1, s. 325.

${ }^{62}$ Emanuel Ringelblum, Stosunki polsko-żydowskie w czasie drugiej wojny światowej (uwagi i spostrzeżenia) [w:] Archiwum Ringelbluma. Konspiracyjne Archiwum Getta Warszawy, t. 29a: Pisma Emanuela Ringelbluma z bunkra, oprac. Eleonora Bergman, Tadeusz Epsztein, Magdalena Siek, Warszawa: ŻıH, 2018. 
uwadze, że to raczej skrót myślowy odwołujący się do złożonej i zniuansowanej rzeczywistości.

Również to, że bez większego zastanowienia mówimy o relacjach „polsko-żydowskich", wydaje się świadectwem etnicyzacji dyskursu o tym, co podczas wojny działo się między Żydami a ich nieżydowskim otoczeniem. W języku ówczesnej epoki mówiło się raczej o Żydach i chrześcijanach. Nawet przedwojenni antysemici wzywający do bojkotu handlu żydowskiego namawiali do kupowania w sklepach chrześcijańskich, a nie polskich. To, że dziś tak interesują nas „stosunki polsko-żydowskie” w czasie wojny, świadczy chyba bardziej o naszym skupieniu na własnym autowizerunku niż o tym, by owe stosunki charakteryzowały się jakąś wyjątkową specyfiką. Zarówno gdy mówimy o pomocy Żydom, jak i postawach przeciwnych, warto pamiętać, że to, co wydarzyło się między Polakami i Żydami, było fragmentem szerszej okupacyjnej rzeczywistości naszej części Europy.

Początkowe partie eseju wstępnego przedstawiają w sposób syntetyczny położenie ludności polskiej pod okupacją niemiecką, a następnie kolejne etapy niemieckich prześladowań Żydów w Generalnym Gubernatorstwie i na ziemiach wcielonych do Rzeszy. Jest to wywód rzeczowy, lecz pojawiają się w nim znamienne dysproporcje w rozłożeniu akcentów. Podrozdział "Droga do Zagłady” (s. 26-31) opisuje zagładę Żydów polskich sensu stricto od masowych egzekucji na Wschodzie podczas operacji „Barbarossa” do zakończenia akcji „Reinhardt” oraz podaje szacunki liczby zamordowanych i liczby ocalałych. Niemal połowę objętości tego, skądinąd bardzo skrótowego, podrozdziału poświęcono będącym w perspektywie Zagłady zaledwie epizodem pogromom Żydów w Łomżyńskiem i na Białostocczyźnie na przełomie czerwca i lipca 1941 r., ich niemieckiej inspiracji oraz stereotypowi kolaboracji Żydów z Sowietami. Sądzę, że ta dysproporcja mimowolnie świadczy o tym, jak bardzo reaktywny wobec, mówiąc umownie, sprawy Jedwabnego charakter mają projekt „Indeks” i omawiana praca.

Głównym przedmiotem mojej krytyki jest jednak stanowiący połowę objętości eseju wstępnego podrozdział „Czynniki kształtujące relacje polsko-żydowskie”. Cały ten utrzymany w defensywnym tonie wywód sprawia wrażenie odpowiedzi na niewypowiedziany zarzut niewystarczającego zaangażowania Polaków w pomaganie Żydom. Znajdujemy tu cały zestaw tradycyjnych usprawiedliwień, od dekad obecnych w dyskursie polsko-żydowskim.

A zatem jedną z przyczyn obojętności na los Żydów było to, że zostali odizolowani w gettach, toteż trudno było ich wspierać materialnie i moralnie; nieobecność Żydów w przestrzeni codziennego doświadczenia prowadziła do obniżenia empatii wobec nich. Formułując za niebędącym historykiem Zagłady Marcinem Zarembą te argumenty, autorki pominęły fakt, że większość gett w okupowanej Polsce miała charakter otwarty lub półotwarty. Stereotypowy obraz getta otoczonego murem był w GG prawdziwy bodaj tylko w odniesieniu do Warszawy, Krakowa i Nowego Sącza. Okazje do kontaktów polsko-żydowskich istniały, o czym autorki zresztą dalej piszą, poruszając kwestię handlu i szmuglu. 
Wiele uwagi autorki poświęcają, idąc tropem Grzegorza Berendta ${ }^{63}$, materialnym aspektom pomocy dla Żydów. Przedstawianie kwestii finansowych jako jednego z najważniejszych (sądząc po ilości miejsca, jakie temu poświęcono) czynników warunkujących postawy wobec Żydów podczas Zagłady wydaje się nieporozumieniem. W tekście szczegółowo omówiono ciężkie położenie materialne Polaków podczas okupacji, ale co to ma wyjaśniać i czego dowodzić? Trudno to odebrać inaczej niż jako usprawiedliwienie, że Polacy powstrzymywali się od pomocy Żydom, bo to dużo kosztowało.

Oczywiście prawdziwy jest argument, że pomaganie Żydom było zabronione pod groźbą śmierci. Praca przynosi dowody, jak bardzo poważne było to zagrożenie. Kiedy jednak autorki przywołują słynny dekret Hansa Franka z 15 października 1941 r., który w polskim dyskursie historycznym funkcjonuje jako akt prawny wprowadzający karę śmierci za pomoc dla Żydów, warto pamiętać, że jego ostrze skierowane było przede wszystkim przeciw samym Żydom. Rozporządzenie to zakazywało im pod groźbą kary śmierci opuszczania gett bez zezwolenia (oznaczało to drakońskie zaostrzenie sankcji za złamanie analogicznego zakazu obowiązującego już wcześniej). Obwarowany identyczną karą zakaz udzielania zbiegłym Żydom schronienia miał charakter subsydiarny wobec pierwszego zakazu. Wskazują na to zarówno konstrukcja tego przepisu, jak i sam tytuł rozporządzenia: „o ograniczeniach pobytu w Generalnym Gubernatorstwie". W pierwszym roku obowiązywania tego rozporządzenia karę śmierci wykonywano wyłącznie wobec Żydów (w Warszawie pierwsza egzekucja ośmiorga Żydów za nielegalne opuszczenie getta odbyła się 17 listopada 1941 r.). W przypadku Polaków zagrożenie śmiercią za pomoc Żydom stało się realne rok później64. Przeskoki autorek w narracji między jesienią 1941 a jesienią 1942 r. (kiedy wydano serię rozporządzeń przypominających o zakazie pomocy Żydom) zacierają tę różnicę ${ }^{65}$.

Realne podstawy miały też wspomniane przez autorki obawy przed wymuszeniem od Żydów schwytanych przez Niemców informacji o tym, kto ich ukrywał. Takie przypadki opisano w dokumentacyjnej części pracy. Ale przecież z tego samego materiału wynika, że pięciokrotnie częściej represje na ratujących ściągnęły nie informacje wydobyte przemocą od Żydów, lecz donosy sąsiedzkie.

\footnotetext{
${ }^{63}$ Grzegorz Berendt, Cena życia - ekonomiczne uwarunkowania egzystencji Żydów po „aryjskiej stronie”, „Zagłada Żydów. Studia i Materiały” 2008, nr 4.

${ }^{64} \mathrm{~W}$ tym świetle nietrafna wydaje się argumentacja Bogdana Musiała, że polska pomoc dla Żydów była tak rozpowszechniona, iż dla jej ukrócenia zostało wydane rozporządzenie Hansa Franka z 15 X 1941 r. (Musiał, Kto dopomoże Żydowi...).

${ }^{65}$ Pierwszy odnotowany w książce wypadek skazania Polaka na śmierć za pomoc Żydom wystąpił w maju 1942 r. w Poznaniu. Leon Stroszczyński dostarczał chleb Żydom osadzonym w obozie pracy przymusowej. Wyrok na nim został wykonany 14 XII 1942 r. (Represje..., s. 199). Przypadek ten nie miał jednak związku z prawodawstwem okupacyjnym obowiązującym w GG.
} 
W tym kontekście dość rażące wydaje się nazwanie takich wymuszonych zeznań „współpracą Żydów z Niemcami”

W niektórych miejscach analiza czynników kształtujących relacje polsko-żydowskie zbliża się niebezpiecznie do obwiniania ofiar. Echo zarzutu, że Żydzi sami nie chcieli sobie pomóc, zdaje się pobrzmiewać w stwierdzeniu: „Nierzadko też sami Żydzi [...] popadali w stan apatii i nie podejmowali działań zmierzających do zmiany położenia” (s. 36). W innym miejscu czytamy: „Nie bez znaczenia w budowaniu relacji polsko-żydowskich w okresie wojny była rola przedstawicieli powstałych wówczas tzw. elit żydowskich albo przynajmniej to, jak ich rolę postrzegano przez pryzmat różnych informacji przedostających się na tzw. aryjską stronę" (s. 51). Z dalszego ciągu wynika, że chodzi o członków judenratów i Żydowskiej Służby Porządkowej, którym zarzuca się uległość wobec okupanta, bierność, brak woli walki i niewzywanie do oporu. Taka konstrukcja wywodu jawi się jako kolejne, nie wprost, usprawiedliwienie polskiej bierności wobec Zagłady. Podobną rolę odgrywają, jak sądzę, budowane w narracji symetrie. Autorki nie pomijają kwestii przywłaszczania przez Polaków mienia należącego do wymordowanych Żydów, co wyjaśniają w pierwszej kolejności zubożeniem społeczeństwa. Zaraz potem nie omieszkają jednak przypomnieć, że szabrem zajmowali się także żydowscy policjanci czy członkowie żydowskiej administracji gett.

To zadziwiające, jak wiele wysiłku poświęcono w eseju wstępnym na neutralizację niezwerbalizowanego zarzutu o braku adekwatnej pomocy dla Żydów. Gdy czyta się te wywody, przychodzi na myśl wezwanie Jana Błońskiego sformułowane w słynnym eseju z 1987 r.: „Przestać się bronić, usprawiedliwiać, targować. Podkreślać, czego nie mogliśmy zrobić za okupacji lub dawniej. Zrzucać winę na uwarunkowania polityczne, społeczne, ekonomiczne. Powiedzieć najpierw: tak, jesteśmy winni”"67. A przecież nie żyjemy już w czasach Błońskiego. Wiemy dziś wystarczająco dużo, by zdawać sobie sprawę, że podstawowym problemem, z jakim trzeba nam się mierzyć, był nie tyle brak pomocy Żydom w przetrwaniu, ile aktywne działanie, by to przetrwanie uniemożliwić. Czyli ochotnicze lub na rozkaz włączenie się wielu Polaków (i nie tylko Polaków) w dzieło zagłady Żydów. Ta świadomość potęguje wrażenie nieadekwatności krytykowanych tu wywodów do stanu debaty publicznej, która zaszła już znacznie dalej, a także do przedstawionego w książce materiału, dotyczącego wszak nie okupacyjnych win Polaków wobec Żydów, ale zasług.

Gdy mowa o „czynnikach kształtujących relacje polsko-żydowskie”, wielkim nieobecnym w eseju wstępnym jest natomiast problem antysemityzmu. A prze-

${ }^{66}$ Inkryminowany passus brzmi: „Do współpracy Żydów z Niemcami dochodziło także w przestrzeni udzielania im pomocy. Zdarzało się, o czym szerzej można przeczytac w prezentowanych w tomie notach, że ukrywający się Żydzi zostali złapani przez Niemców i mając nadzieję na ocalenie życia, przekazywali informację o osobach, które dały im schronienie" (Represje..., s. 52).

${ }^{67}$ Jan Błoński, Biedni Polacy patrzą na getto, „Tygodnik Powszechny”, 11 I 1987, nr 2. 
cież to niechęć do Żydów, traktowanie ich jako obcych, niechcianych i wrogich, rozplenione w społeczeństwie polskim (i nie tylko polskim ${ }^{68}$ ) już przed wojną, były jedną z podstawowych determinant stosunku Polaków do Żydów podczas wojny. Mówiły o tym wprost dokumenty Polskiego Państwa Podziemnego, by wymienić znaną depeszę z 25 września 1941 r., w której gen. Stefan Rowecki uświadamiał premierowi Władysławowi Sikorskiemu, że „przygniatająca większość kraju jest nastrojona antysemicko" ${ }^{\prime 69}$. Autorki piszą o antysemickiej propagandzie szerzonej przez niemieckiego okupanta, co konkludują następującym zdaniem: „Pozostaje otwarte pytanie, jaki był realny wpływ tych działań na ludność nieżydowską" (s. 24). Godziłoby się tu zauważyć, że propagowany przez Niemców obraz Żydów jako chciwych, przewrotnych, dążących do władzy i panowania nad światem, siejących rozkład moralny pasożytów, burżujów, a zarazem bolszewików nie był nowy, lecz tożsamy z przedwojenną propagandą antysemicką w Polsce. Propaganda niemiecka trafiała na podatny grunt, bo niosła treści doskonale znane i zinternalizowane przez znaczną część społeczeństwa polskiego. Nie tyle wytwarzała niechęć do Żydów, ile umacniała już zakorzeniony antysemityzm. To właśnie była owa wspomniana przez Jana Karskiego „wąska kładka”, na której „spotykali się zgodnie Niemcy i duża część polskiego społeczeństwa"70.

Nie wątpię, że autorki są świadome znaczenia tych uwarunkowań, lecz można odnieść wrażenie, jakby przed dobitnym postawieniem roli antysemityzmu powstrzymywało je jakieś tabu. Istnienie antysemityzmu jako istotnego czynnika kształtującego relacje polsko-żydowskie jest jakby nieśmiało sugerowane, można przeczytać o nim między wierszami, doszukać się odwołań do niego w różnych enigmatycznych sformułowaniach. Na przykład gdy mowa o antyżydowskich wystąpieniach i dyskryminacji Żydów przed wojną, pojawia się zdanie: „Ważne były także wyznawane przed wojną i podczas niej poglądy polityczne” (s. 34). 0 co chodzi w tym zagadkowym stwierdzeniu? Dopiero z przypisu, jakim zostało opatrzone, gdzie znajdujemy odesłania do prac o stosunku endecji do Żydów oraz do monografii Falangi Szymona Rudnickiego, można się z zorientować, że chodzi tu o polityczny antysemityzm, który odpowiadał za przemoc wobec Żydów. W innym miejscu, gdy mowa o plądrowaniu żydowskiego majątku, czytamy: „Przejmowanie mienia Żydów [...] było związane raczej ze zubożeniem ludności i ograniczeniami w dostępie do towarów niż z kwestiami ideologicznymi" (s. 41). Cóż to za tajemnicze kwestie ideologiczne? Czy chodzi po prostu o antysemityzm? Czy autorki chciały przez to powiedzieć, że sąsiedzi grabili

${ }^{68} \mathrm{Z}$ najnowszej literatury zob. Götz Aly, Europe against the Jews 1880-1945, New York: Metropolitan Books, 2020.

${ }^{69}$ Polacy-Żydzi 1939-1945. Wybór źródet, red. Andrzej Krzysztof Kunert, Warszawa: ROPWiM i Rytm, 2001, s. 197.

${ }^{70}$ Jan Karski, Zagadnienie żydowskie w Polsce pod okupacjami, „Mówią Wieki” 1992, nr 4, s. 3-8. 
„pożydowskie” mienie nie dlatego, że byli antysemitami, lecz z biedy? Wygląda to tak, jakby słowo „antysemityzm” nie chciało wypłynąć autorkom spod pióra. O ile czegoś nie przeoczyłem, pojawia się ono tylko w cytatach, a nie w tekście odautorskim. Czy to jakieś zewnętrzne ograniczenia skłaniały autorki do ukrywania się przy poruszaniu kwestii antysemityzmu Polaków za cytatami?

Niedopowiedzenia, eufemizmy, budowanie symetrii, asekuracyjne sformułowania są cechami charakterystycznymi języka eseju wstępnego. Czytamy na przykład o „wzajemnych uprzedzeniach” oraz „przedwojennych antagonizmach głównie na tle ekonomicznym" (s. 43) - a przecież, mówiąc wprost, chodziło o wyrugowanie Żydów z gospodarki; i nie było tu żadnej symetrii, nie Żydzi występowali w tej sytuacji jako agresor. Gdy autorki piszą o roli policji granatowej, podsumowują to następująco: „W związku z pełnioną służbą i wykonywaniem rozkazów zarzuca się członkom tej formacji współudział w Zagładzie. Problematyka ta jest jednak bardzo złożona i wymaga krytycznego podejścia oraz konfrontacji wielu źródeł" (s. 47). Odbieram to jako rozmywanie na poziomie języka problemu, zwłaszcza że chwilę wcześniej autorki podały konkretne przykłady działań tejże policji, które można jednoznacznie zakwalifikować jako współudział w zagładzie Żydów. Pewnym usprawiedliwieniem jest być może to, że omawiana praca ukazała się przed książką Jana Grabowskiego, która przyniosła właśnie taki, postulowany przez autorki, komplementarny, oparty na szerokiej bazie źródłowej i niepozostawiający wątpliwości obraz zaangażowania policji granatowej w ludobójstwo ${ }^{71}$. Wreszcie w podsumowaniu eseju wstępnego czytamy: „Badania nad relacjami polsko-żydowskimi w czasie wojny wymagają szczególnej ostrożności. [...] Dlatego też pisząc o postawach polskiego społeczeństwa wobec Żydów, należy uwzględniać wiele czynników: wielowymiarowość okupacyjnych realiów, kontekst zdarzeń, a także okoliczności, które wywołały potrzebę relacji. W badaniach naukowych, zwłaszcza nad tak złożoną tematyką, należy unikać nieuzasadnionych generalizacji czy powierzchownych sądów" (s. 63). Niby to wszystko prawda, ale czyta się te przestrogi jak zestaw asekuranckich komunałów. Miejscami lawirowanie w obronie okupacyjnego wizerunku Polaków staje się zresztą tak czytelne, że sprawia wrażenie, jakby autorki same nie były w pełni przekonane do formułowanych przez siebie argumentów. A może właśnie to nam między wierszami sygnalizują?

Tymczasem defensywny ton eseju wstępnego był zgoła niepotrzebny. W części dokumentacyjnej książki zgromadzono bogaty, nowy materiał faktograficzny. Wprawdzie można się spierać o reprezentatywność ilościową opisanych przypadków represji za pomoc Żydom, ale bez większego ryzyka można je uznać

${ }^{71}$ Grabowski, Na posterunku... W omawianym tekście nie zacytowano natomiast ważnego artykułu tego autora na temat roli podległej niemieckiej Policji Bezpieczeństwa polskiej Policji Kryminalnej w wyszukiwaniu ukrywających się Żydów. Zob. Jan Grabowski, Tropiąc

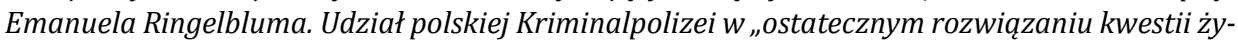
dowskiej”, „Zagłada Żydów. Studia i Materiały” 2014, nr 10, t. 1. 
za reprezentatywne pod względem fenomenologicznym, zwłaszcza dla Polski centralnej, gdzie rozegrało się 81 procent tych historii (dystrykty warszawski, radomski, krakowski i lubelski GG, rejencja ciechanowska, okręg białostocki). Byłoby więc może bardziej przydatne, gdyby redaktorki tomu pokusiły się o zarysowanie na tej podstawie syntetycznego, jakościowego obrazu realiów związanych ze świadczeniem Żydom pomocy i zagrożeniami, jakie to za sobą pociągało. Opis okupacyjnej rzeczywistości, jaką poznajemy dzięki szeroko zakrojonym badaniom w ramach projektu „Indeks”, byłby chyba właściwszym wstępem do omawianej książki, lepiej wykorzystującym potencjał materiału zebranego przez zespół autorski.

Nie całkiem udany esej wstępny nie zmienia jednak faktu, że otrzymaliśmy rzetelną, wartościową pracę, wnoszącą dużą porcję nowej wiedzy. Być może ten krytykowany wyżej wstęp jest signum temproris wskazującym, że wracają czasy, w których by powiedzieć coś ważnego, niekoniecznie idącego z prądem oficjalnej polityki historycznej, trzeba się okupić, zostawiając diabłu ogarek.

\section{BIBLIOGRAFIA}

Aly Götz, Europe against the Jews 1880-1945, New York: Metropolitan Books, 2020.

Arad Yitzhak, The Operation Reinhard Death Camps. Belzec, Sobibor, Treblinka, wyd. popr. i rozsz., Bloomington: Indiana University Press, 2018.

Babińska Maria, Bilewicz Michał, Bulska Dominika, Haska Agnieszka, Winiewski Mikołaj, Stosunek do Żydów i ich historii po wprowadzeniu ustawy o IPN, analiza przygotowana na zlecenie Biura Rzecznika Praw Obywatelskich, Centrum Badań nad Uprzedzeniami, Warszawa 2018 (druk elektroniczny, https://www.rpo.gov.pl/ sites/default/files/Analiza_Skutki_ustawy_o_IPN.pdf).

Bańkowska Aleksandra, Partyzantka polska z lat 1942-1944 w relacjach żydowskich, „Zagłada Żydów. Studia i Materiały" 2005, nr 1.

Ten jest z ojczyzny mojej. Polacy z pomoca Żydom 1939-1945, oprac. Władysław Bartoszewski, Zofia Lewinówna, Warszawa: Świat Książki, 2007.

Berendt Grzegorz, Cena życia - ekonomiczne uwarunkowania egzystencji Żydów po „aryjskiej stronie”, „Zagłada Żydów. Studia i Materiały” 2008, nr 4.

Bikont Anna, My z Jedwabnego, Warszawa: Prószyński i S-ka, 2004 (wyd. 2, Wołowiec: Czarne, 2012).

Bikont Anna, Sendlerowa. W ukryciu, Wołowiec: Czarne, 2017.

Bikont Anna, Żegota jako organizacja Żydów i Polaków [w:] Żydzi w walce z nazistowskimi Niemcami podczas drugiej wojny światowej, red. Krzysztof Persak (w przygotowaniu).

Błoński Jan, Biedni Polacy patrzq na getto, „Tygodnik Powszechny”, 11 I 1987, nr 2.

Cała Alina, Ochrona bezpieczeństwa fizycznego Żydów w Polsce powojennej. Komisje specjalne przy Centralnym Komitecie Żydów w Polsce, Warszawa: ŻIH, 2014.

Chodakiewicz Marek Jan, Mord w Jedwabnem 10 lipca 1941. Prolog, przebieg, pokłosie, Kraków: Wyd. Arkadiusz Wingert, 2012.

Chodakiewicz Marek Jan, Po Zagładzie. Stosunki polsko-żydowskie 1944-1947, Warszawa: IPN, 2008.

Cichopek Anna, Pogrom Żydów w Krakowie 11 sierpnia 1945, Warszawa: ŻıH, 2000.

Czaczkowska Ewa, Uratujmy pamięć Sprawiedliwych, „Rzeczpospolita”, 27 V 2008. 
Dalej jest noc. Losy Żydów w wybranych powiatach okupowanej Polski, t. 1-2, red. Barbara Engelking, Jan Grabowski, Warszawa: Stowarzyszenie Centrum Badań nad Zagładą Żydów, 2018.

Domański Tomasz, Korekta obrazu? Refleksje źródłoznawcze wokół ksiq̨żki „Dalej jest noc. Losy Żydów w wybranych powiatach okupowanej Polski”, Warszawa: IPN, 2019.

Domański Tomasz, Korekty ciąg dalszy. Odpowiedź redaktorom i współautorom książki Dalej jest noc. Losy Żydów w wybranych powiatach okupowanej Polski, red. B. Engelking, J. Grabowski, Warszawa 2018 na ich polemikę z mojq̨ recenzjq Korekta obrazu? Refleksje źródłoznawcze wokół książki Dalej jest noc. Losy Żydów w wybranych powiatach okupowanej Polski, t. 1-2, red. Barbara Engelking, Jan Grabowski, Warszawa 2018, Warszawa 2019, Warszawa: IPN, 2020.

Eksterminacja Żydów na ziemiach polskich w okresie okupacji hitlerowskiej. Zbiór dokumentów, red. Tatiana Berenstein, Artur Eisenbach, Adam Rutkowski, Warszawa: Ż̇H, 1957.

Engelking Barbara, Jest taki piękny słoneczny dzień. Losy Żydów szukających ratunku na wsi polskiej 1942-1945, Warszawa: Stowarzyszenie Centrum Badań nad Zagładą Żydów, 2011.

Engelking Barbara, „Szanowny panie gistapo”. Donosy do władz niemieckich $w$ Warszawie i okolicach w latach 1940-1941, Warszawa: IFiS PAN, 2003.

Engelking Barbara, Żydzi pomagający innym Żydom w ukrywaniu się po aryjskiej stronie $w$ Warszawie [w:] Żydzi w walce z nazistowskimi Niemcami podczas drugiej wojny światowej, red. Krzysztof Persak (w przygotowaniu).

Forecki Piotr, Od „Shoah” do „Strachu”. Spory o polsko-żydowskq przeszłość i pamięć w debatach publicznych, Poznań: Wydawnictwo Poznańskie, 2010.

Forecki Piotr, Po Jedwabnem. Anatomia pamięci funkcjonalnej, Warszawa: IBL PAN, 2018.

Forecki Piotr, Zawadzka Anna, Reguła złotego środka. Kilka uwag na temat współczesnego dominującego dyskursu o „stosunkach polsko-żydowskich”, „Zagłada Żydów. Studia i Materiały" 2015, nr 11.

Frydel Tomasz, Powiat dębicki [w:] Dalej jest noc. Losy Żydów w wybranych powiatach okupowanej Polski, t. 2, red. Barbara Engelking, Jan Grabowski, Warszawa: Stowarzyszenie Centrum Badań nad Zagładą Żydów, 2018.

Gieroń Roman, Półmrok. Procesy karne w sprawie przestępstw okupacyjnych popełnionych przez chłopów wobec Żydów w województwie krakowskim, Kraków: IPN, 2020.

Godni synowie naszej Ojczyzny. Świadectwa nadesłane na apel Radia Maryja, t. 1-2, red. Alicja Augustyniak, Warszawa: Wydawnictwo Sióstr Loretanek, 2002.

Górny Grzegorz, Sprawiedliwi. Jak Polacy ratowali Żydów przed Zagładą, Izabelin-Warszawa: Rosikon Press, 2013.

Grabowski Jan, „Ja tego Żyda znam!” Szantażowanie Żydów w Warszawie, 1939-1943, Warszawa: IFiS PAN, 2004.

Grabowski Jan, Judenjagd. Polowanie na Żydów 1942-1945. Studium dziejów pewnego powiatu, Warszawa: Stowarzyszenie Centrum Badań nad Zagładą Żydów, 2011.

Grabowski Jan, Na posterunku. Udział polskiej policji granatowej i kryminalnej w zagładzie Żydów, Wołowiec: Czarne, 2020.

Grabowski Jan, Tropiq̨c Emanuela Ringelbluma. Udział polskiej Kriminalpolizei $w$ „ostatecznym rozwiązaniu kwestii żydowskiej”, „Zagłada Żydów. Studia i Materiały” 2014, nr 10, t. 1.

Gross Jan Tomasz, Sąsiedzi. Historia zagłady żydowskiego miasteczka, Sejny: Pogranicze, 2000.

Gross Jan Tomasz, Strach. Antysemityzm w Polsce tuż po wojnie. Historia moralnej zapaści, Kraków: Znak, 2008. 
Gross Jan Tomasz, Grudzińska-Gross Irena, Złote żniwa. Rzecz o tym, co się działo na obrzeżach zagłady Żydów, Kraków: Znak, 2011.

Hera Janina, Polacy ratujący Żydów. Słownik, Warszawa: Neriton, 2014.

Inferno of Choices. Poles and the Holocaust, red. Sebastian Rejak, Elżbieta Frister, wyd. 2 popr. i rozsz., Warsaw: Rytm, 2012.

Iranek-Osmecki Kazimierz, Kto ratuje jedno życie... Polacy i Żydzi 1939-1945, Warszawa: IPN, 2009.

„Jak ci się uda uratować, pamiętaj”. Relacje „Sprawiedliwych" i o „Sprawiedliwych” z województwa zachodniopomorskiego, red. Paweł Knap, Szczecin: IPN, 2010.

Kaczmarski Krzysztof, Pogrom, którego nie było. Rzeszów 11-12 czerwca 1945 r. Fakty, hipotezy, dokumenty, Rzeszów: IPN, 2008.

Karski Jan, Zagadnienie żydowskie w Polsce pod okupacjami, „Mówią Wieki” 1992, nr 4.

Klucze i kasa. O mieniu żydowskim w Polsce pod okupacją niemieckq i we wczesnych latach powojennych 1939-1950, red. Jan Grabowski, Dariusz Libionka, Warszawa: Stowarzyszenie Centrum Badań nad Zagładą Żydów, 2014.

Kopówka Edward, Rytel-Andrianik Paweł, Dam im imię na wieki. Polacy z okolic Treblinki ratujący Żydów, Oxford-Treblinka: Wydawnictwo Sióstr Loretanek, 2011.

Korboński Stefan, Polacy, Żydzi i Holocaust, Warszawa: IPN, 2011.

Kowalska-Leder Justyna, „Nie wiem, jak mam ich cenić...” Strefa ambiwalencji w świadectwach Polaków i Żydów, Warszawa: IBL PAN, 2019.

Kowalska-Leder Justyna, Wszechobecność Sprawiedliwych, „Zagłada Żydów. Studia i Materiały" 2014, nr 10, t. 2.

Kranz Tomasz, Zagłada Żydów w obozie koncentracyjnym na Majdanku, Lublin: Państwowe Muzeum na Majdanku, 2010.

Krzyżanowski Łukasz, Dom, którego nie było. Powroty ocalałych do powojennego miasta, Wołowiec: Czarne, 2016.

Księga Sprawiedliwych wśród Narodów Świata. Ratujący Żydów podczas Holocaustu. Polska, red. Israel Gutman, red. wyd. polskiego Dariusz Libionka, Robert Kuwałek, Adam Kopciowski, Kraków: Fundacja Instytutu Studiów Strategicznych, 2009.

„Kto w takich czasach Żydów przechowuje?...” Polacy niosący pomoc ludności żydowskiej w okresie okupacji niemieckiej, red. Aleksandra Namysło, Warszawa: IPN, 2009.

Kurek Ewa, Dzieci żydowskie w klasztorach. Udział żeńskich zgromadzeń zakonnych wakcji ratowania dzieci żydowskich $w$ Polsce $w$ latach 1939-1945, Zakrzewo: Replika, 2012.

Kuwałek Robert, Nowe ustalenia dotyczqce liczby ofiar niemieckiego obozu zagłady w Sobiborze, „Zeszyty Majdanka” 2014, nr 26.

Kuwałek Robert, Obóz zagłady w Bełżcu, Lublin: Państwowe Muzeum na Majdanku, 2010.

Lata czterdzieste. Początki polskiej narracji o Zagładzie, red. Maryla Hopfinger, Tomasz Żukowski, Warszawa: IBL PAN, 2019.

Leociak Jacek, Ratowanie. Opowieści Polaków i Żydów, Kraków: Wydawnictwo Literackie, 2010.

Libionka Dariusz, Antysemityzm i Zagłada na łamach prasy w Polsce w latach 1945-1946, „Polska 1944/45. Studia i materiały” 1997, t. 2.

Libionka Dariusz, Polskie piśmiennictwo na temat zorganizowanej i indywidualnej pomocy Żydom (1945-2008), „Zagłada Żydów. Studia Materiały” 2008, nr 4.

Libionka Dariusz, Powiat miechowski [w:] Dalej jest noc. Losy Żydów w wybranych powiatach okupowanej Polski, t. 2, red. Barbara Engelking, Jan Grabowski, Warszawa: Stowarzyszenie Centrum Badań nad Zagładą Żydów, 2018.

Madaj Karol, Żuławnik Małgorzata, Proboszcz getta, Warszawa: IPN, 2010. 
Markiel Tadeusz, Skibińska Alina, „Jakie to ma znaczenie, czy zrobili to z chciwości?”. Zagłada domu Trynczerów, Warszawa: Stowarzyszenie Centrum Badań nad Zagładą Żydów, 2011.

Mędykowski Witold, W cieniu gigantów. Pogromy 1941 r. w byłej sowieckiej strefie okupacyjnej kontekst historyczny, społeczny i kulturowy, Warszawa: ISP PAN, 2012.

Młynarczyk Jacek, Piątkowski Sebastian, Cena poświęcenia. Zbrodnie na Polakach za pomoc udzielana Żydom w rejonie Ciepielowa, Kraków: ISS, 2007.

Montague Patrick, Chełmno. Pierwszy nazistowski obóz zagłady, tłum. Tomasz S. Gałązka, Wołowiec: Czarne, 2014.

Musiał Bogdan, Kto dopomoże Żydowi, współpraca Oliver Musiał, Poznań: Zysk i S-ka, 2019.

Następstwa zagłady Żydów. Polska 1944-2010, red. Feliks Tych, Monika Adamczyk-Garbowska, Lublin: UMCS i ŻIH, 2012.

Nieudana korekta obrazu. Odpowiedzi redaktorów tomów oraz autorów poszczególnych rozdziałów na broszurę autorstwa dr. Tomasza Domańskiego, http://www.holocaustresearch.pl/index.php?show=555.

Opowieść o niewinności. Kategoria świadka Zagłady w kulturze polskiej (1942-2015), red. Maryla Hopfinger, Tomasz Żukowski, Warszawa: IBL PAN, 2019.

Pamięć i nadzieja, Warszawa: Fundacja Lux Veritatis, 2017.

Piper Franciszek, Ilu ludzi zginęło w KL Auschwitz, Oświęcim: Wydawnictwo Państwowego Muzeum w Oświęcimiu, 1992.

Podbielska Alicja, Święta rodzina z Markowej. Kult Ulmów i polityka historyczna, „Zagłada Żydów. Studia i Materiały" 2019, nr 15.

Pogromy Żydów na ziemiach polskich w XIX i XX wieku, t. 4: Holokaust i powojnie (19391946), red. August Grabski, IH PAN i in., Warszawa 2019.

Polacy-Żydzi 1939-1945. Wybór źródeł, red. Andrzej K. Kunert, Warszawa: ROPWiM i Rytm, 2001.

Polacy i Żydzi pod okupacja niemiecka 1939-1945. Studia i materiały, red. Andrzej Żbikowski, Warszawa: IPN, 2006.

Polacy ratujący Żydów w czasie Zagłady. Przywracanie pamięci, Warszawa: IPN, 2016.

Polacy ratujący Żydów w latach II wojny światowej, oprac. Kamila Sachnowska, Katarzyna Cegieła, Karol Madaj, Olga Tumińska, Warszawa: IPN, 2008 (seria „Teki Edukacyjne IPN”).

Prekerowa Teresa, Konspiracyjna Rada Pomocy Żydom w Warszawie 1942-1945, Warszawa: PIW, 1982 (wyd. 2 2019).

Prowincja noc. Życie i zagłada Żydów w dystrykcie warszawskim, red. Barbara Engelking, Jacek Leociak, Dariusz Libionka, Warszawa: IFiS PAN, 2007.

Rączy Elżbieta, Pomoc Polaków dla ludności żydowskiej na Rzeszowszczyźnie 1939-1945, Rzeszów: IPN, 2008.

Rączy Elżbieta, Witowicz Igor, Polacy ratujący Żydów na Rzeszowszczyźnie w latach 1939-1945, Rzeszów: IPN, 2011.

Rejestr faktów represji na obywatelach polskich za pomoc ludności żydowskiej w okresie II wojny światowej, red. Aleksandra Namysło, Grzegorz Berendt, Warszawa: IPN i ISS, 2014 (druk elektroniczny).

Relacje o pomocy udzielanej Żydom przez Polaków w latach 1939-1945, red. Sebastian Piątkowski, t. 1: Dystrykt warszawski Generalnego Gubernatorstwa, Warszawa: IPN, 2018; t. 2: Dystrykt krakowski Generalnego Gubernatorstwa, Warszawa: IPN, 2020; t. 3: Dystrykt lubelski Generalnego Gubernatorstwa, Warszawa: IPN, 2020; t. 4: Dystrykt radomski Generalnego Gubernatorstwa, Warszawa: IPN, 2020.

Represje za pomoc Żydom na okupowanych ziemiach polskich w czasie II wojny światowej, t. 1, red. Martyna Grądzka-Rejak, Aleksandra Namysło, Warszawa: IPN, 2019. 
Ringelblum Emanuel, Stosunki polsko-żydowskie w czasie drugiej wojny światowej (uwagi i spostrzeżenia) [w:] Archiwum Ringelbluma. Konspiracyjne Archiwum Getta Warszawy, t. 29a: Pisma Emanuela Ringelbluma z bunkra, oprac. Eleonora Bergman, Tadeusz Epsztein, Magdalena Siek, Warszawa 2018.

Rusiniak Martyna, Obóz zagłady Treblinka II w pamięci społecznej (1943-1989), Warszawa: Neriton, 2008.

Skibińska Alina, Powiat biłgorajski [w:] Dalej jest noc. Losy Żydów w wybranych powiatach okupowanej Polski, t. 1, red. Barbara Engelking, Jan Grabowski, Warszawa: Stowarzyszenie Centrum Badań nad Zagładą Żydów, 2018.

Skibińska Alina, Tokarska-Bakir Joanna, Barabasz i Żydzi. Z historii oddziału AK „Wybranieccy”, „Zagłada Żydów. Studia i Materiały” 2011, nr 7.

Sprawiedliwi i ich świat. Markowa w fotografii Józefa Ulmy, red. Mateusz Szpytma, Kraków: IPN, 2015.

Szarek Jarosław, Szpytma Mateusz, Rodzina Ulmów. Whołdzie miłosiernym. Przejmująca historia polskiej rodziny, która poświęciła swoje życie, ratując Żydów, Kraków: Rafael, 2014.

Szarota Tomasz, U progu Zagłady. Zajścia antyżydowskie i pogromy w okupowanej Europie Warszawa, Paryż, Amsterdam, Antwerpia, Kowno, Warszawa: Sic!, 2000.

Szpytma Mateusz, The Risk of Survival. The Rescue of the Jews by the Poles and the Tragic Consequences for the Ulma Family, Warszawa: IPN, 2009.

Szulikowska Maria Elżbieta, Markowskie bociany. Opowieść o bohaterskiej rodzinie Wiktorii i Józefa Ulmów, Przemyśl: Wydawnictwo Archidiecezji Przemyskiej, 2017.

Those Who Helped. Polish Rescuers of Jews during the Holocaust, red. Ryszard Walczak i in., Warszawa: IPN, 1997.

Tokarska-Bakir Joanna, Bracia miesiace. Studia z antropologii historycznej Polski 19391946, Warszawa: IBL PAN (w druku).

Tokarska-Bakir Joanna, Okrzyki pogromowe. Szkice z antropologii historycznej Polski lat 1939-1946, Wołowiec: Czarne, 2012.

Tokarska-Bakir Joanna, Pod klątwa. Społeczny portret pogromu kieleckiego, t. 1-2, Warszawa: Czarna Owca, 2018.

Tryczyk Mirosław, Miasta śmierci. Sq̨siedzkie pogromy Żydów, Warszawa: Wydawnictwo RM, 2015.

Urynowicz Marcin, Zorganizowana i indywidualna pomoc Polaków dla ludności żydowskiej eksterminowanej przez okupanta niemieckiego w okresie drugiej wojny światowej [w:] Polacy i Żydzi pod okupacją niemieckq 1939-1945. Studia i materiały, red. Andrzej Żbikowski, Warszawa: IPN, 2006.

Wokół Jedwabnego, t. 1-2, red. Paweł Machcewicz, Krzysztof Persak, Warszawa: IPN, 2002. Wokół pogromu kieleckiego, red. Łukasz Kamiński, Jan Żaryn, Warszawa: IPN, 2006.

Zagłada Żydów i stosunki polsko-żydowskie podczas II wojny światowej. Katalog publikacji 2000-2019, IPN, Warszawa 2019.

Zarys krajobrazu. Wieś polska wobec zagłady Żydów 1942-1945, red. Barbara Engelking, Jan Grabowski, wstęp Krzysztof Persak, Warszawa: Stowarzyszenie Centrum Badań nad Zagładą Żydów, 2011.

Złote serca czy złote żniwa? Studia nad wojennymi losami Polaków i Żydów, red. Marek Jan Chodakiewicz, Wojciech Jerzy Muszyński, Warszawa: The Facto, 2011.

Żaryn Jan, Polacy ratujący Żydów. Historie niezwykłe, Warszawa: Neriton, 2014.

Żbikowski Andrzej, U genezy Jedwabnego. Żydzi na Kresach Północno-Wschodnich II Rzeczypospolitej wrzesień 1939 - lipiec 1941, Warszawa: Ż̇H, 2006.

Żukowski Tomasz, Wielki retusz. Jak zapomnieliśmy, że Polacy zabijali Żydów, Warszawa: Wielka Litera, 2018. 